\title{
Bis(diisopropylamino)cyclopropenium-arene Cations as High Oxidation Potential and High Stability Catholytes for Nonaqueous Redox Flow Batteries
}

Yichao Yan, Thomas P. Vaid, and Melanie S. Sanford*

Department of Chemistry, University of Michigan, 930 North University Avenue, Ann Arbor, Michigan 48109, United States

Joint Center for Energy Storage Research (JCESR), 9700 S. Cass Avenue, Argonne, Illinois 60439, United States

\section{Table of Contents}

I. Synthetic Procedures S2

II. $\quad{ }^{1} \mathrm{H},{ }^{13} \mathrm{C}$, and ${ }^{19} \mathrm{~F}$ NMR Spectra $\quad$ S8

III. DFT Calculation Methods and Data $\quad$ S20

IV. Electrochemistry Experimental Procedures $\quad$ S22

V. Additional Electrochemical Data $\quad$ S26

VI. Representative Reported Organic and Organometallic Catholytes $\quad$ S35

VII. Cost Analysis of the Synthesis of $\left[\mathbf{3 g}^{+}\right]\left[\mathrm{PF}_{6}\right] \quad$ S36

$\begin{array}{ll}\text { VIII. References } & \text { S37 }\end{array}$ 


\section{Synthetic Procedures}

General Information. All commercial chemicals were used as received unless stated otherwise. Anhydrous $\mathrm{CH}_{2} \mathrm{Cl}_{2}$ was obtained from an Innovative Technology, Inc. (now rebranded to Inert) solvent purification system. Reactions were performed under a nitrogen atmosphere. Dialkoxybenzene derivatives were synthesized according to literature procedures. ${ }^{1,2}$ Butyl viologen was synthesized according to literature procedures ${ }^{3}$ and then anion exchanged with $\mathrm{NH}_{4} \mathrm{PF}_{6}$. The solubility of $\left[\mathbf{3 g}^{+}\right]\left[\mathrm{PF}_{6}\right]$ in acetonitrile was determined using a previously reported method. ${ }^{4}$ NMR spectra were obtained on Varian VNMRs 700, Varian VNMRs 500, Varian Inova 500, or Varian MR400 spectrometers. ${ }^{1} \mathrm{H}$ and ${ }^{13} \mathrm{C}$ chemical shifts are reported in parts per million (ppm) relative to TMS, with the residual solvent peak used as an internal reference. ${ }^{19} \mathrm{~F}$ chemical shifts are reported relative to the $\mathrm{PF}_{6}{ }^{-}$anions at $-72.82 \mathrm{ppm}$, determined from an internal standard of fluorobenzene at $-114.81 \mathrm{ppm}$ in $\mathrm{CD}_{3} \mathrm{CN} .{ }^{5}$ High resolution mass spectroscopy (HRMS) was performed on a Micromass AutoSpec Ultima Magnetic Sector Mass Spectrometer using electrospray ionization (ESI).

\section{General procedure for the synthesis of bis(diisopropylamino)cyclopropenium-arenes.} (Based on reported procedures. $\left.{ }^{6,7}\right)$ Tetrachlorocyclopropene (120 mg, $\left.0.67 \mathrm{mmol}\right)$ and $\mathrm{AlCl}_{3}(88$ $\mathrm{mg}, 0.66 \mathrm{mmol}$ ) were mixed in $2 \mathrm{~mL}$ of $\mathrm{CH}_{2} \mathrm{Cl}_{2}$ at room temperature for $15 \mathrm{~min}$ to form a white suspension. The mixture was cooled to $0{ }^{\circ} \mathrm{C}$ and the appropriate benzene derivative $(0.66 \mathrm{mmol}$, dissolved in $2 \mathrm{~mL} \mathrm{CH}_{2} \mathrm{Cl}_{2}$ ) was added slowly to the reaction mixture. Stirring was continued at $0{ }^{\circ} \mathrm{C}$ for $2 \mathrm{~h}$ and then diisopropylamine $(271 \mathrm{mg}, 2.68 \mathrm{mmol})$ was slowly added. The resulting mixture was stirred at $0{ }^{\circ} \mathrm{C}$ for $30 \mathrm{~min}$. The reaction mixture was then filtered, and the filtrate was washed with $10 \mathrm{~mL}$ of a 1:1 solution of brine and $2 \mathrm{M} \mathrm{HCl}$. The aqueous layer was extracted with $\mathrm{CH}_{2} \mathrm{Cl}_{2}(2 \times 15 \mathrm{~mL})$, and the combined organic fractions were concentrated under vacuum. The resulting residue was dissolved in $5 \mathrm{~mL}$ of water, and an aqueous solution of ammonium 
hexafluorophosphate $\left(\mathrm{NH}_{4} \mathrm{PF}_{6} ; 218 \mathrm{mg}, 1.34 \mathrm{mmol}\right.$ in $\left.2 \mathrm{~mL} \mathrm{H} 2 \mathrm{O}\right)$ was added with vigorous stirring. A precipitate formed, and this material was extracted into $\mathrm{CH}_{2} \mathrm{Cl}_{2}(3 \times 15 \mathrm{~mL})$. The organic extracts were dried over $\mathrm{MgSO}_{4}$ and concentrated under vacuum. The product was then purified by chromatography on silica gel with gradient elution (0-5\% acetonitrile in $\left.\mathrm{CH}_{2} \mathrm{Cl}_{2}\right)$. The main fractions were then collected and reduced under vacuum to a concentrated solution. Excess diethyl ether was added to precipitate the product, and the resulting white solid was collected via filtration.

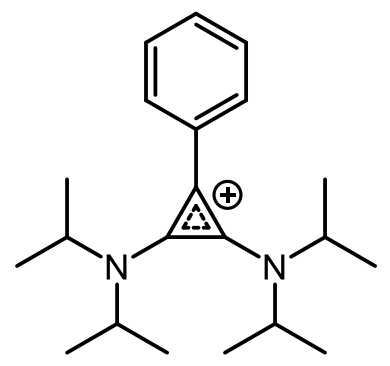

Synthesis of $\left[\mathbf{3 a}^{+}\right]\left[\mathbf{P F}_{\mathbf{6}}\right]$ : The general procedure was followed using benzene as the substrate. $\left[\mathbf{3 a}^{+}\right]\left[\mathrm{PF}_{6}\right]$ was isolated as a white powder $(79 \mathrm{mg}, 29 \%) . \mathrm{R}_{\mathrm{F}}=0.24 \mathrm{in} 5 \%$ acetonitrile $/ \mathrm{CH}_{2} \mathrm{Cl}_{2} .{ }^{1} \mathrm{H}$ NMR (401 MHz, CD $\left.{ }_{3} \mathrm{CN}\right) \delta$ 7.63-7.56 (m, 3H), 7.48-7.43 (m, 2H), 4.08 (sept, $\left.J=6.9 \mathrm{~Hz}, 2 \mathrm{H}\right)$, 3.86 (sept, $J=6.8 \mathrm{~Hz}, 2 \mathrm{H}), 1.37$ (d, $J=6.8 \mathrm{~Hz}, 12 \mathrm{H}), 1.17(\mathrm{~d}, J=6.8 \mathrm{~Hz}, 12 \mathrm{H}) .{ }^{13} \mathrm{C}$ NMR $(126$ $\left.\mathrm{MHz}, \mathrm{CD}_{3} \mathrm{CN}\right) \delta 134.81,131.35,130.51,129.52,127.65,108.54,57.90,48.91,21.55,20.75$. HRMS (ESI) $m / z$ calcd for $\mathrm{C}_{21} \mathrm{H}_{33} \mathrm{~N}_{2}\left(\mathbf{3 a}^{+}\right)$: 313.2638, found 313.2636.

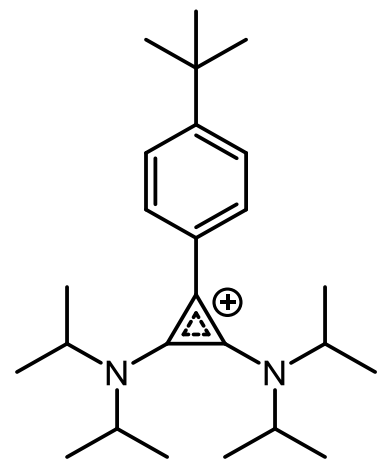

Synthesis of $\left[\mathbf{3 b}^{+}\right]\left[\mathbf{P F}_{6}\right]$ : The general procedure was followed using tert-butylbenzene as the substrate. $\left[3 \mathbf{b}^{+}\right]\left[\mathrm{PF}_{6}\right]$ was isolated as a white powder $(243 \mathrm{mg}, 47 \%) . \mathrm{R}_{\mathrm{F}}=0.22$ in $5 \%$ 
acetonitrile/ $\mathrm{CH}_{2} \mathrm{Cl}_{2} .{ }^{1} \mathrm{H}$ NMR $\left(700 \mathrm{MHz}, \mathrm{CD}_{3} \mathrm{CN}\right) \delta 7.65(\mathrm{dd}, J=8.3,2.4 \mathrm{~Hz}, 2 \mathrm{H}), 7.42(\mathrm{dd}, J=$ 8.3, $2.4 \mathrm{~Hz}, 2 \mathrm{H}), 4.11$ (sept, $J=7.4 \mathrm{~Hz}, 2 \mathrm{H}), 3.89$ (sept, $J=7.1 \mathrm{~Hz}, 2 \mathrm{H}), 1.38$ (d, $J=6.7 \mathrm{~Hz}, 12 \mathrm{H}$ ), $1.37(\mathrm{~s}, 9 \mathrm{H}), 1.21(\mathrm{~d}, J=6.7 \mathrm{~Hz}, 12 \mathrm{H}) .{ }^{13} \mathrm{C} \mathrm{NMR}\left(176 \mathrm{MHz}, \mathrm{CD}_{3} \mathrm{CN}\right) \delta 154.86,134.80,129.37$, $127.50,124.32,108.85,57.68,49.13,35.60,31.29,21.64,20.87$. HRMS (ESI) $\mathrm{m} / z$ calcd for $\mathrm{C}_{25} \mathrm{H}_{41} \mathrm{~N}_{2}\left(\mathbf{3 b}^{+}\right): 369.3264$, found 369.3267 .

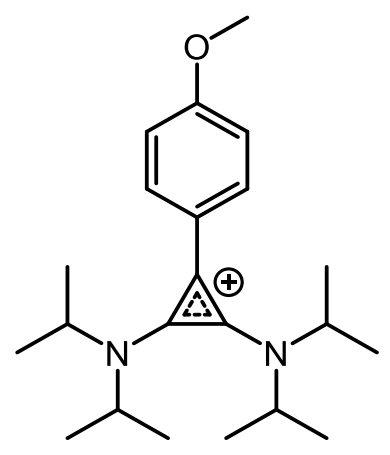

Synthesis of $\left[\mathbf{3 c}^{+}\right]\left[\mathbf{P F}_{6}\right]$ : The general procedure was followed using anisole as the substrate. $\left[3 \mathbf{c}^{+}\right]\left[\mathrm{PF}_{6}\right]$ was isolated as a white powder $(112 \mathrm{mg}, 35 \%) . \mathrm{R}_{\mathrm{F}}=0.21$ in $5 \%$ acetonitrile $/ \mathrm{CH}_{2} \mathrm{Cl}_{2}$. ${ }^{1} \mathrm{H}$ NMR (401 MHz, CD ${ }_{3} \mathrm{CN}$ ) $\delta$ 7.47-7.36 (m, 2H), 7.17-7.08 (m, 2H), 4.07 (sept, $J=6.6 \mathrm{~Hz}, 2 \mathrm{H}$ ), 3.89 (sept, 2H), 3.86 (s, 3H), 1.36 (d, $J=6.8 \mathrm{~Hz}, 12 \mathrm{H}), 1.20$ (d, $J=6.8 \mathrm{~Hz}, 12 \mathrm{H}) .{ }^{13} \mathrm{C}$ NMR $(176$ $\left.\mathrm{MHz}, \mathrm{CD}_{3} \mathrm{CN}\right) \delta 162.15,134.84,131.29,118.78,115.98,108.91,57.62,56.25,49.14,21.68$, 20.89. HRMS (ESI) $m / z$ calcd for $\mathrm{C}_{22} \mathrm{H}_{35} \mathrm{~N}_{2} \mathrm{O}\left(\mathbf{3 c}^{+}\right)$: 343.2744 , found 343.2741 .

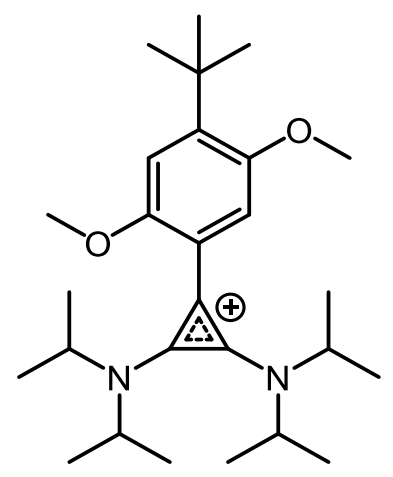

Synthesis of $\left[\mathbf{3 d}^{+}\right]\left[\mathbf{P F}_{\mathbf{6}}\right]$ : The general procedure was followed using 1-tert-butyl-2,5dimethoxybenzene as the substrate. $\left[\mathbf{3 d}^{+}\right]\left[\mathrm{PF}_{6}\right]$ was isolated as a white powder $(112 \mathrm{mg}, 30 \%) .{ }^{1} \mathrm{H}$ 
NMR (401 MHz, CD $\left.{ }_{3} \mathrm{CN}\right) \delta 7.06(\mathrm{~s}, 1 \mathrm{H}), 6.88(\mathrm{~s}, 1 \mathrm{H}), 4.10$ (sept, $\left.J=6.7 \mathrm{~Hz}, 2 \mathrm{H}\right), 3.86$ (sept, $J=$ $6.7 \mathrm{~Hz}, 2 \mathrm{H}), 3.79$ (s, 3H), 3.78 (s, 3H), 1.41 (s, 9H), 1.37 (d, $J=6.7 \mathrm{~Hz}, 12 \mathrm{H}), 1.17$ (d, $J=6.7 \mathrm{~Hz}$, 12H). ${ }^{13} \mathrm{C}$ NMR (176 MHz, $\left.\mathrm{CD}_{3} \mathrm{CN}\right) \delta 153.66,151.55,143.36,135.75,113.72,112.68,112.07$, 107.07, 57.65, 56.57, 56.54, 49.12, 36.14, 29.67, 21.68, 20.91. HRMS (ESI) $\mathrm{m} / \mathrm{z}$ calcd for $\mathrm{C}_{27} \mathrm{H}_{45} \mathrm{~N}_{2} \mathrm{O}_{2}\left(\mathbf{3 d}^{+}\right): 429.3476$, found 429.3479 .

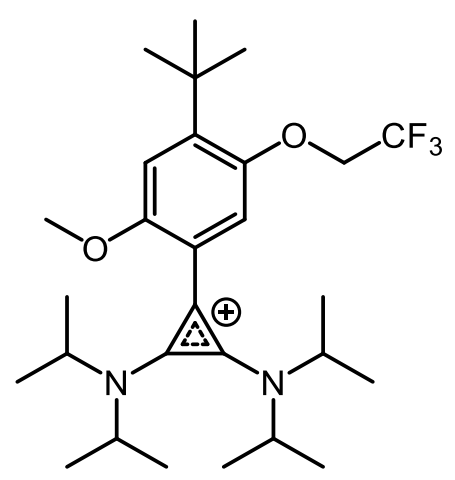

Synthesis of $\left[3 \mathbf{e}^{+}\right]\left[\mathbf{P F}_{6}\right]$ : The general procedure was followed using 1-tert-butyl-3-methoxy-6(2,2,2-trifluoroethoxy)benzene as the substrate. $\left[\mathbf{3 e}^{+}\right]\left[\mathrm{PF}_{6}\right]$ was isolated as a white powder (102 $\mathrm{mg}, 16 \%) . \mathrm{R}_{\mathrm{F}}=0.30$ in $5 \%$ acetonitrile/ $\mathrm{CH}_{2} \mathrm{Cl}_{2} .{ }^{1} \mathrm{H}$ NMR $\left(700 \mathrm{MHz}, \mathrm{CD}_{3} \mathrm{CN}\right) \delta 7.12(\mathrm{~s}, 1 \mathrm{H}), 6.86$ (s, 1H), 4.48 (q, $J=8.5 \mathrm{~Hz} 2 \mathrm{H}$ ), 4.12 (sept, $J=6.9 \mathrm{~Hz}, 2 \mathrm{H}$ ), 3.87 (sept, $J=6.8 \mathrm{~Hz}, 2 \mathrm{H}), 3.83$ (s, 3H), 1.45 (s, 9H), 1.38 (d, $J=6.7 \mathrm{~Hz}, 12 \mathrm{H}), 1.17$ (d, $J=6.7 \mathrm{~Hz}, 12 \mathrm{H}) .{ }^{13} \mathrm{C}$ NMR $(176 \mathrm{MHz}$, $\left.\mathrm{CD}_{3} \mathrm{CN}\right) \delta 152.64,150.86,143.74,135.89,125.66,114.42,113.03,112.53,106.53,66.47$ (q, $J=$ $35.3 \mathrm{~Hz}), 57.87,56.69,49.14,36.22,29.74,21.76,20.93 .{ }^{19} \mathrm{~F}$ NMR (377 MHz, $\left.\mathrm{CD}_{3} \mathrm{CN}\right) \delta-72.82$ (d, $J=706.5 \mathrm{~Hz}, \mathrm{PF}_{6}$ ), -74.04 (t, $3 \mathrm{~F}, J=8.4 \mathrm{~Hz}, \mathrm{CF}_{3}$ ). HRMS (ESI) $\mathrm{m} / z$ calcd for $\mathrm{C}_{28} \mathrm{H}_{44} \mathrm{~F}_{3} \mathrm{~N}_{2} \mathrm{O}_{2}$ $\left(3 \mathbf{e}^{+}\right)$: 497.3349, found 497.3348 . 


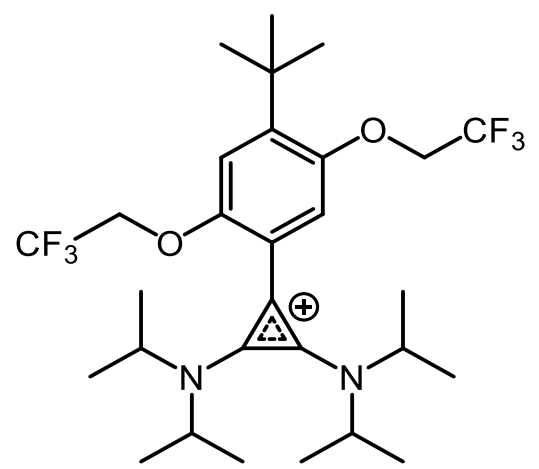

Synthesis of $\left[\mathbf{3 f}^{+}\right]\left[\mathbf{P F}_{\mathbf{6}}\right]$ : The general procedure was followed using 1-tert-butyl-2,5-bis(2,2,2trifluoroethoxy)benzene as the substrate. $\left[\mathbf{3 f}^{+}\right]\left[\mathrm{PF}_{6}\right]$ was isolated as a white powder $(118 \mathrm{mg}, 17 \%)$. $\mathrm{R}_{\mathrm{F}}=0.32$ in $5 \%$ acetonitrile/ $\mathrm{CH}_{2} \mathrm{Cl}_{2} .{ }^{1} \mathrm{H}$ NMR $\left(700 \mathrm{MHz}, \mathrm{CD}_{3} \mathrm{CN}\right) \delta 7.11(\mathrm{~s}, 1 \mathrm{H}), 6.91(\mathrm{~s}, 1 \mathrm{H})$, 4.58 (q, $J=8.4,2 \mathrm{H}), 4.52$ (q, $J=8.5,2 \mathrm{H}), 4.13$ (sept, $J=6.7 \mathrm{~Hz}, 2 \mathrm{H}$ ), 3.87 (sept, $J=6.7 \mathrm{~Hz}, 2 \mathrm{H}$ ), $1.44(\mathrm{~s}, 9 \mathrm{H}), 1.38(\mathrm{~d}, J=6.8 \mathrm{~Hz}, 12 \mathrm{H}), 1.15(\mathrm{~d}, J=6.8 \mathrm{~Hz}, 12 \mathrm{H}) \cdot{ }^{13} \mathrm{C} \mathrm{NMR}\left(176 \mathrm{MHz}, \mathrm{CD}_{3} \mathrm{CN}\right)$ $\delta 152.06,149.67,143.90,136.05,125.33,124.03,123.76,114.27,113.90,105.60,66.82$ (q, $J=$ $35.5 \mathrm{~Hz}), 66.36$ (q, $J=35.4 \mathrm{~Hz}), 58.18,49.07,36.27,29.67,21.77,20.89 .{ }^{19} \mathrm{~F}$ NMR (377 MHz, $\left.\mathrm{CD}_{3} \mathrm{CN}\right) \delta-72.82\left(\mathrm{~d}, J=706.4 \mathrm{~Hz}, \mathrm{PF}_{6}\right),-73.98\left(\mathrm{t}, 3 \mathrm{~F}, J=8.4 \mathrm{~Hz}, \mathrm{CF}_{3}\right),-74.65(\mathrm{t}, 3 \mathrm{~F}, J=8.3 \mathrm{~Hz}$, $\mathrm{CF}_{3}$ ). HRMS (ESI) $m / z$ calcd for $\mathrm{C}_{29} \mathrm{H}_{43} \mathrm{~F}_{6} \mathrm{~N}_{2} \mathrm{O}_{2}\left(\mathbf{3 f}^{+}\right): 565.3223$, found 565.3226 .

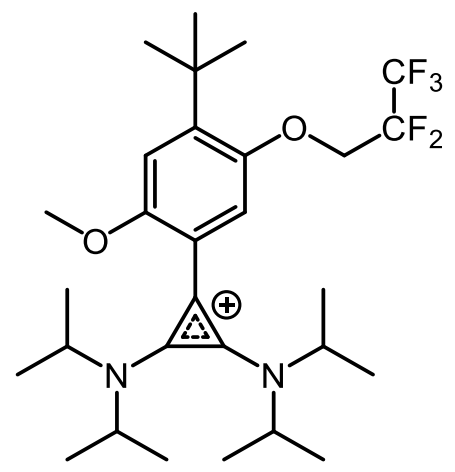

Synthesis of $\left[\mathbf{3 g}^{+}\right]\left[\mathbf{P F}_{\mathbf{6}}\right]$ : The general procedure was followed using 1-tert-butyl-3-methoxy-6(2,2,3,3,3-pentafluoropropoxy)benzene as the substrate. $\left[\mathbf{3 g}^{+}\right]\left[\mathrm{PF}_{6}\right]$ was isolated as a white powder (202 mg, 29\%). $\mathrm{R}_{\mathrm{F}}=0.31$ in 5\% acetonitrile $/ \mathrm{CH}_{2} \mathrm{Cl}_{2} .{ }^{1} \mathrm{H}$ NMR $\left(401 \mathrm{MHz}, \mathrm{CD}_{3} \mathrm{CN}\right) \delta 7.11(\mathrm{~s}, 1 \mathrm{H})$, 6.89 (s, 1H), 4.54 (t, $J=13.4 \mathrm{~Hz}, 2 \mathrm{H}), 4.10$ (sept, $J=6.8 \mathrm{~Hz}, 2 \mathrm{H}), 3.86$ (sept, $J=6.8 \mathrm{~Hz}, 2 \mathrm{H}$ ), 
$3.81(\mathrm{~s}, 3 \mathrm{H}), 1.42(\mathrm{~s}, 9 \mathrm{H}), 1.37(\mathrm{~d}, J=6.7 \mathrm{~Hz}, 12 \mathrm{H}), 1.15(\mathrm{~d}, J=6.7 \mathrm{~Hz}, 12 \mathrm{H}) .{ }^{13} \mathrm{C}$ NMR $(176$ $\left.\mathrm{MHz}, \mathrm{CD}_{3} \mathrm{CN}\right) \delta 152.73,150.99,143.92,135.89,114.74,113.08,112.52,106.51,65.81(\mathrm{t}, J=$ $26.2 \mathrm{~Hz}), 57.88,56.69,49.14,36.21,29.72,21.77,20.93$. The ${ }^{13} \mathrm{C}$ resonances corresponding to the $\mathrm{CF}_{2} \mathrm{CF}_{3}$ group were poorly resolved due to carbon-fluorine coupling. ${ }^{19} \mathrm{~F}$ NMR (377 MHz, $\left.\mathrm{CD}_{3} \mathrm{CN}\right) \delta-72.82\left(\mathrm{~d}, J=705.7 \mathrm{~Hz}, \mathrm{PF}_{6}\right),-84.02\left(\mathrm{~m}, 3 \mathrm{~F}, \mathrm{CF}_{3}\right),-123.33\left(\mathrm{~m}, 2 \mathrm{~F}, \mathrm{CF}_{2}\right)$. HRMS (ESI) $m / z$ calcd for $\mathrm{C}_{29} \mathrm{H}_{44} \mathrm{~F}_{5} \mathrm{~N}_{2} \mathrm{O}_{2}\left(\mathbf{3 g}^{+}\right): 547.3317$, found 547.3320 .

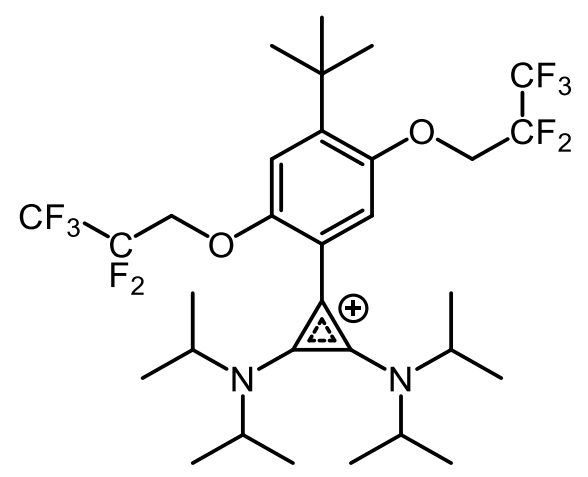

Synthesis of $\left[\mathbf{3 h}^{+}\right]\left[\mathbf{P F}_{\mathbf{6}}\right]$ : The general procedure was followed using 1-tert-butyl-2,5-bis(2,2,3,3,3pentafluoropropoxy)benzene as the substrate. $\left[3 \mathbf{h}^{+}\right]\left[\mathrm{PF}_{6}\right]$ was isolated as a white powder $(107 \mathrm{mg}$, $13 \%) . \mathrm{R}_{\mathrm{F}}=0.31$ in $5 \%$ acetonitrile/ $\mathrm{CH}_{2} \mathrm{Cl}_{2} .{ }^{1} \mathrm{H}$ NMR $\left(401 \mathrm{MHz}, \mathrm{CD}_{3} \mathrm{CN}\right) \delta 7.10(\mathrm{~s}, 1 \mathrm{H}), 6.92(\mathrm{~s}$, 1H), 4.62 (m, 4H), 4.10 (sept, $J=6.8 \mathrm{~Hz}, 2 \mathrm{H}), 3.84$ (sept, $J=6.8 \mathrm{~Hz}, 2 \mathrm{H}), 1.42$ (s, 9H), 1.36 (d, $J$ $=6.7 \mathrm{~Hz}, 12 \mathrm{H}), 1.13(\mathrm{~d}, J=6.7 \mathrm{~Hz}, 12 \mathrm{H}) .{ }^{13} \mathrm{C} \mathrm{NMR}\left(176 \mathrm{MHz}, \mathrm{CD}_{3} \mathrm{CN}\right) 152.21,149.49,144.04$, 135.95, 114.46, 114.04, 113.50, 105.54, 65.90 (t, $J=26.5 \mathrm{~Hz}), 65.64$ (t, $J=26.5 \mathrm{~Hz}), 58.29,49.12$, $36.30,29.64,21.75,20.86$. The ${ }^{13} \mathrm{C}$ resonances corresponding to the $\mathrm{CF}_{2} \mathrm{CF}_{3}$ groups were poorly resolved due to carbon-fluorine coupling. ${ }^{19} \mathrm{~F}$ NMR $\left(377 \mathrm{MHz}, \mathrm{CD}_{3} \mathrm{CN}\right) \delta-72.82(\mathrm{~d}, J=706.4 \mathrm{~Hz}$, $\left.\mathrm{PF}_{6}\right),-83.60\left(\mathrm{~m}, 3 \mathrm{~F}, \mathrm{CF}_{3}\right),-84.07\left(\mathrm{~m}, 3 \mathrm{~F}, \mathrm{CF}_{3}\right),-123.31$ to -123.41 (m, 4F, $\mathrm{CF}_{2}$ ). HRMS (ESI) $m / z$ calcd for $\mathrm{C}_{31} \mathrm{H}_{43} \mathrm{~F}_{10} \mathrm{~N}_{2} \mathrm{O}_{2}\left(\mathbf{3 h}^{+}\right): 665.3159$, found 665.3169 . 


\section{NMR spectra}
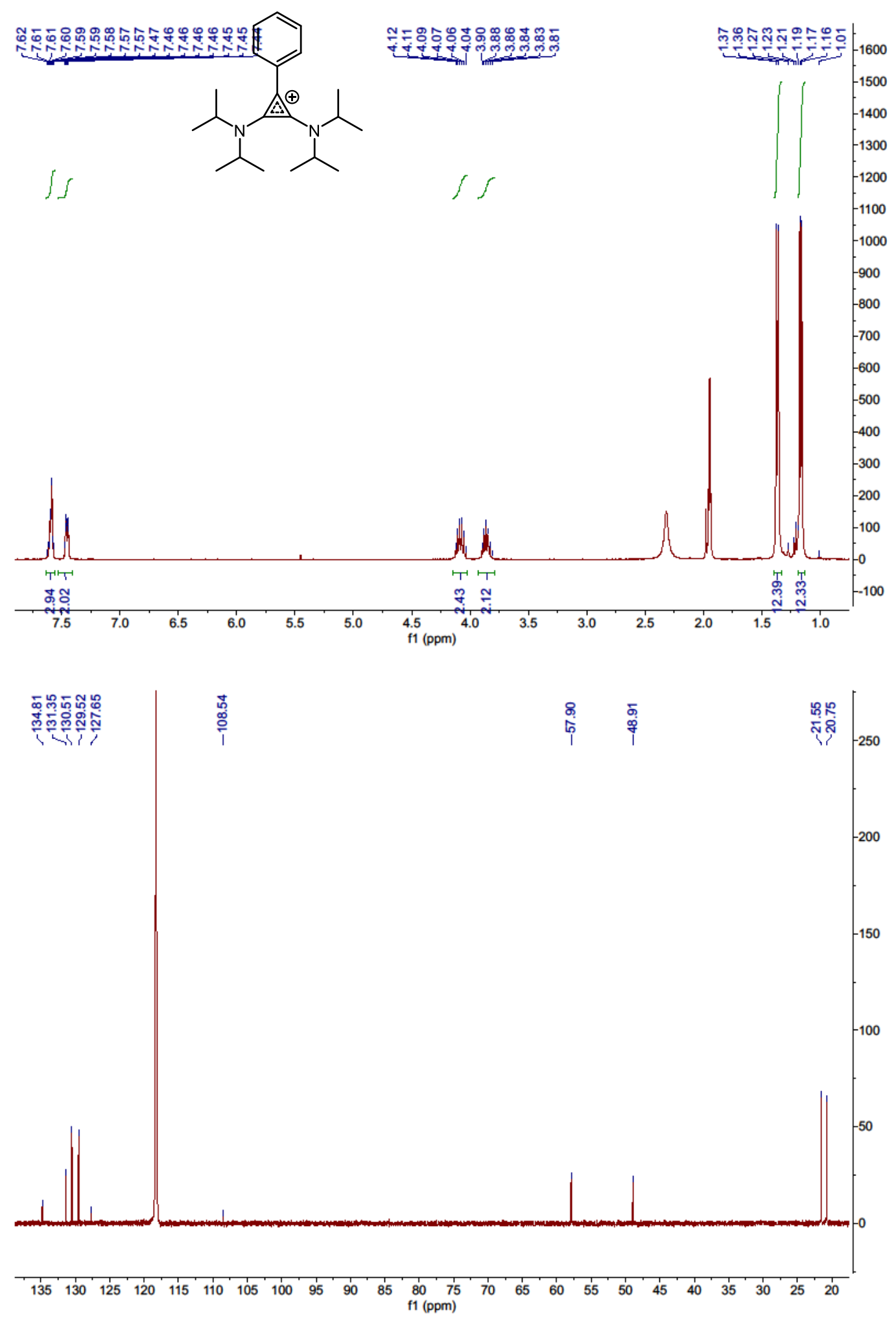


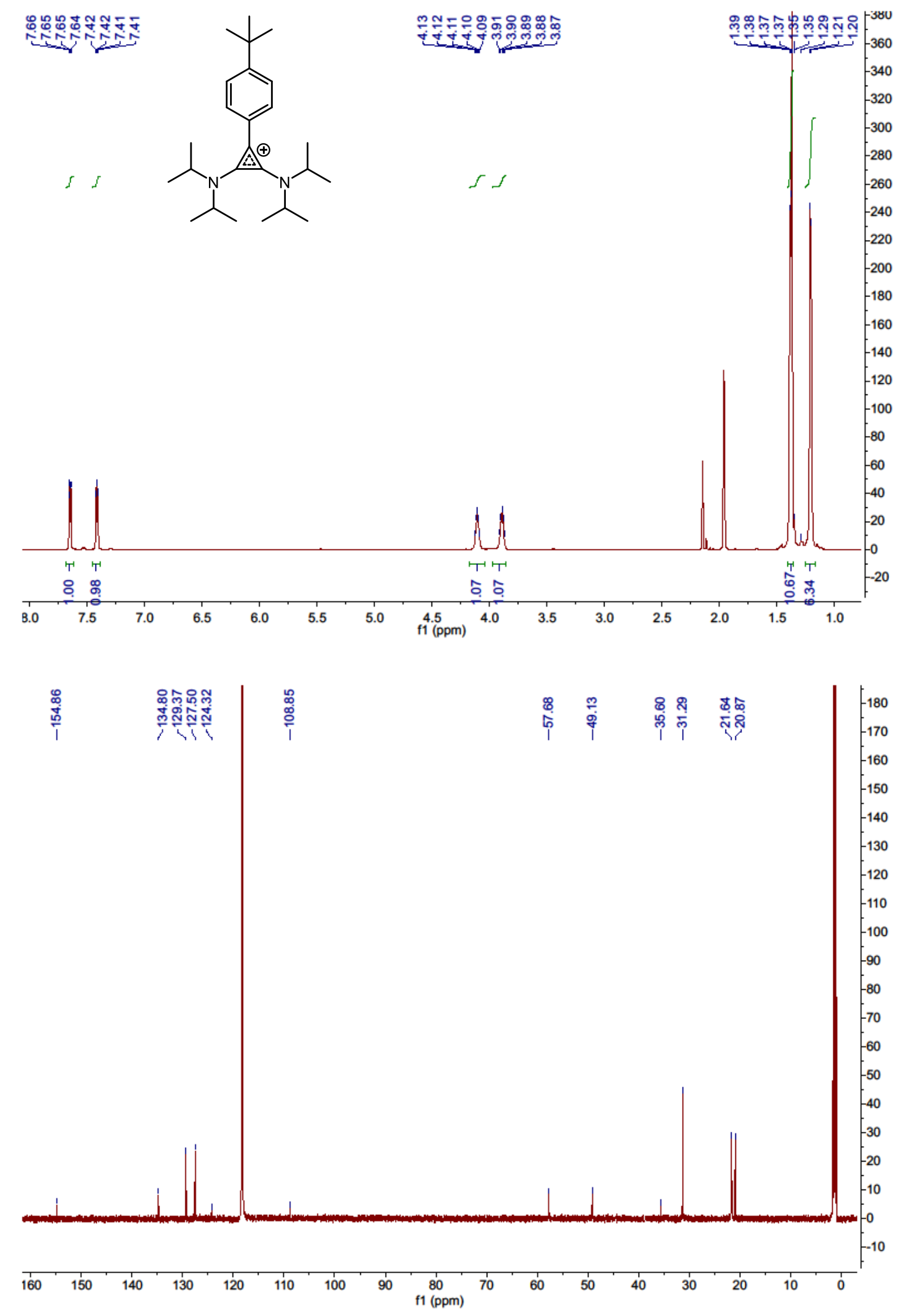



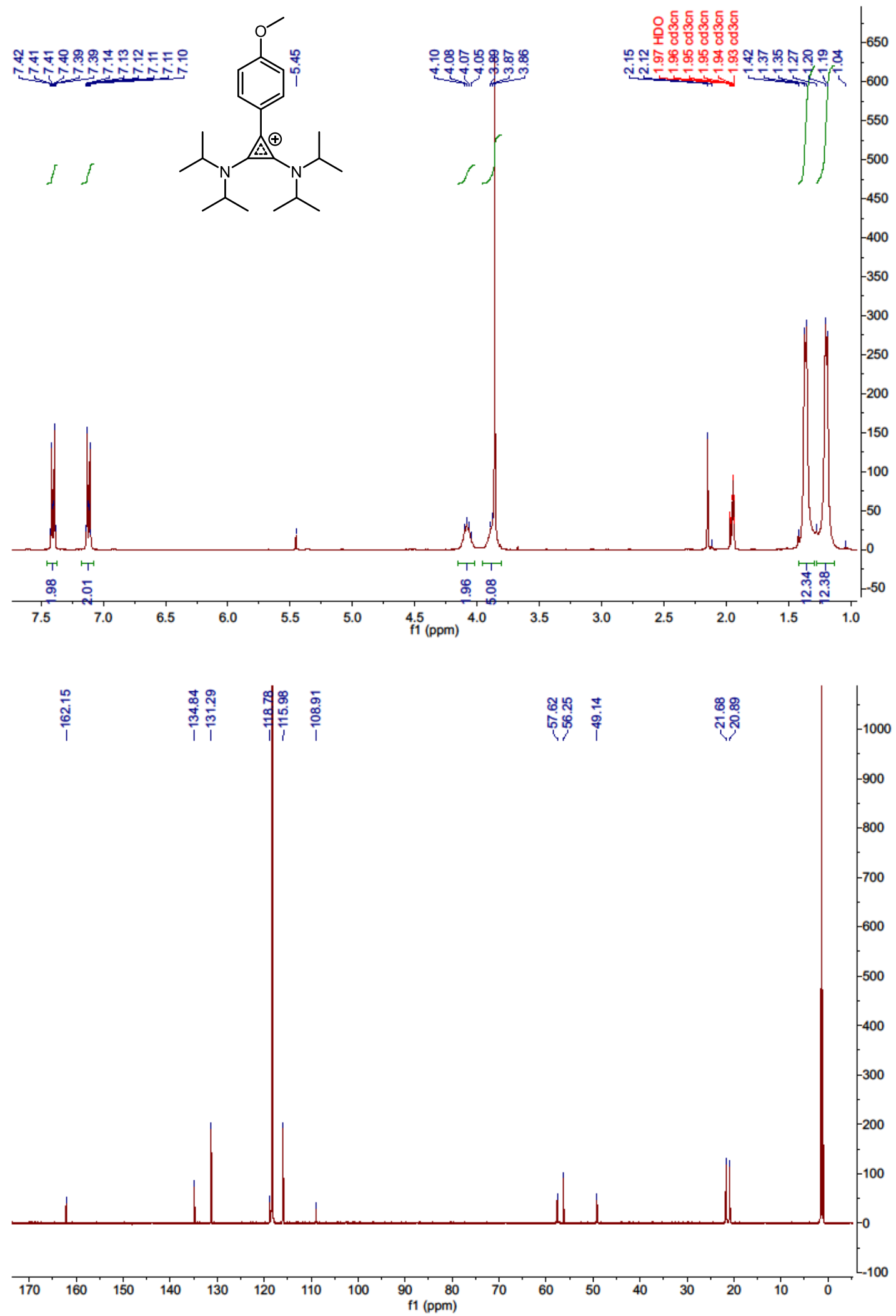

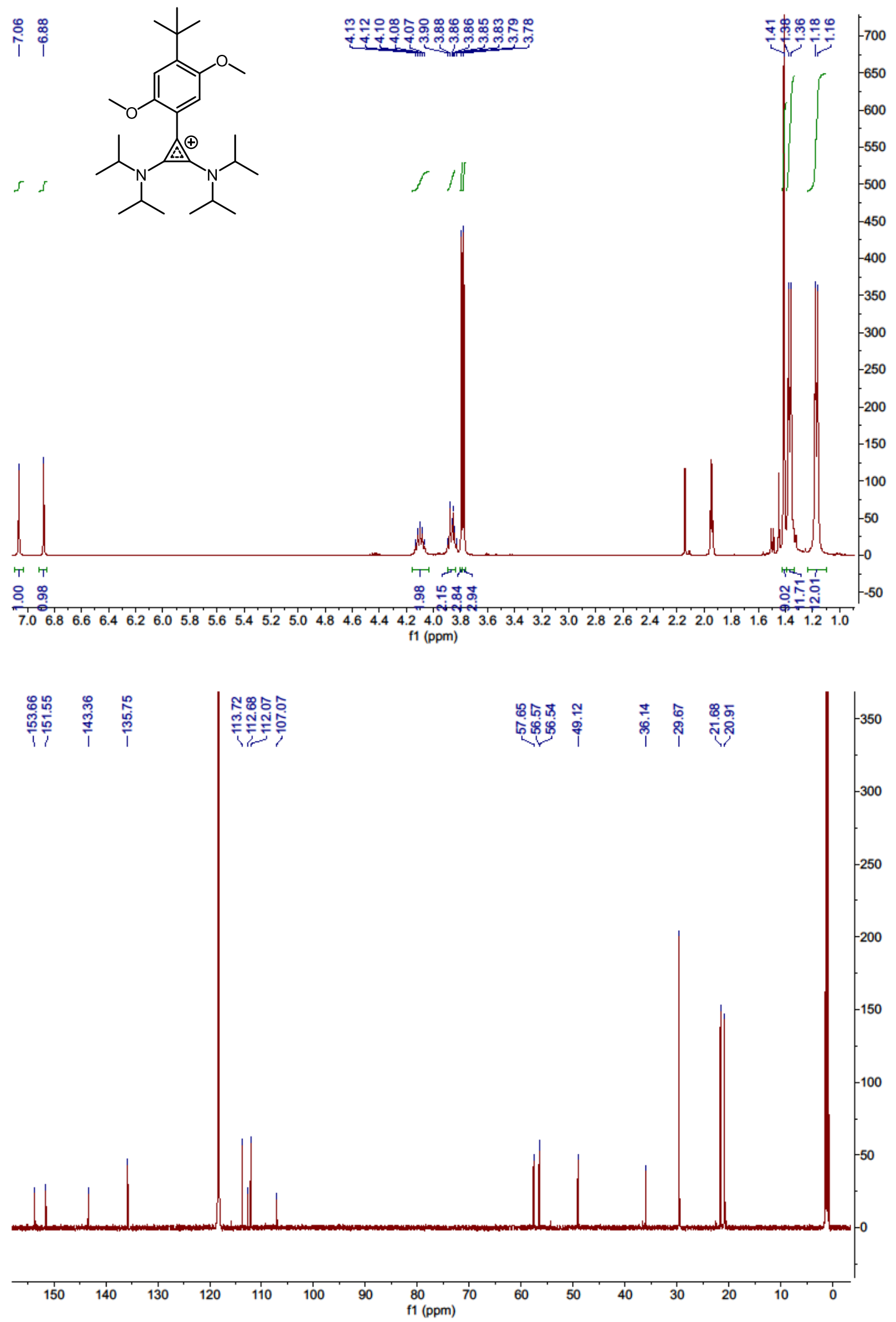


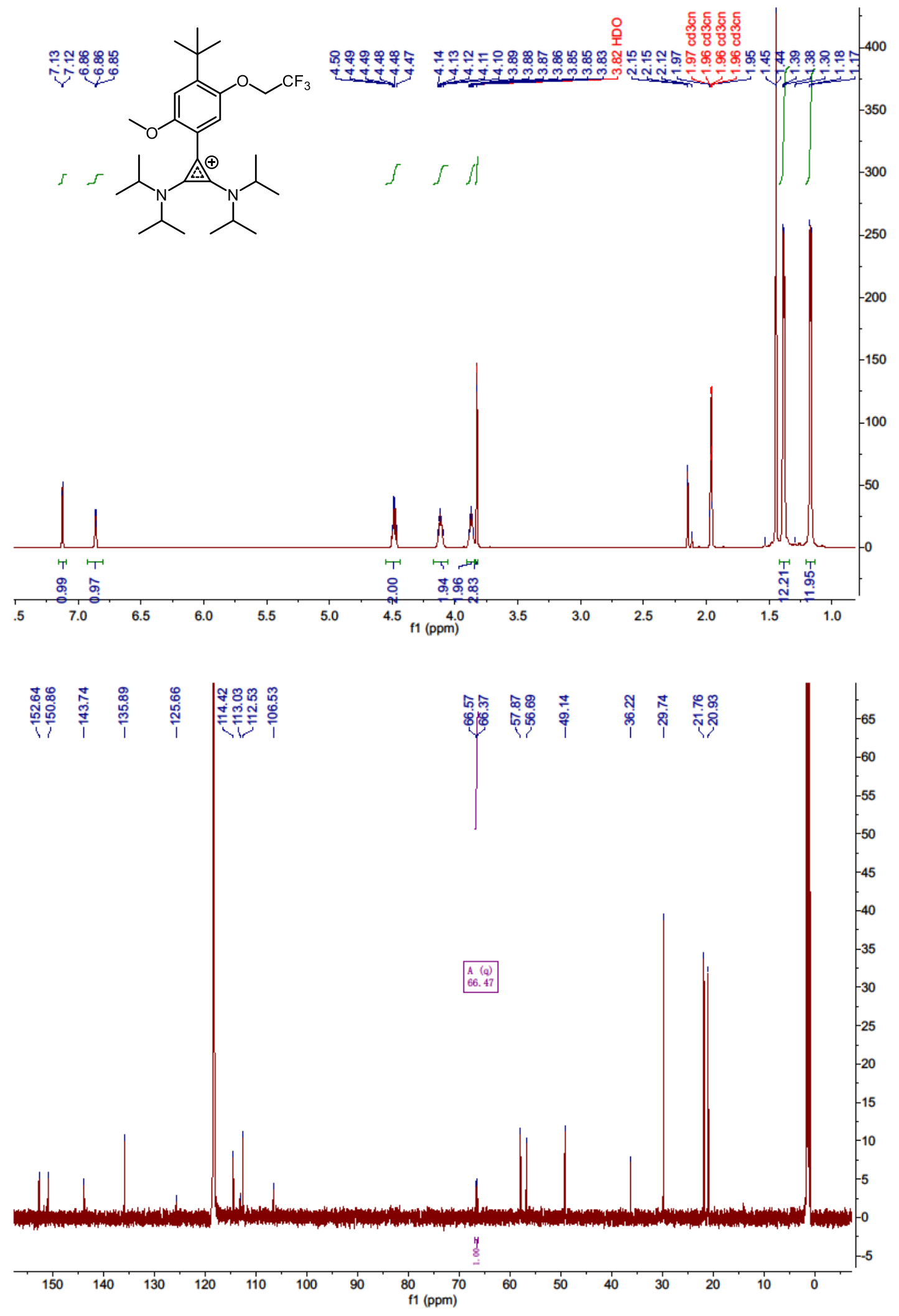




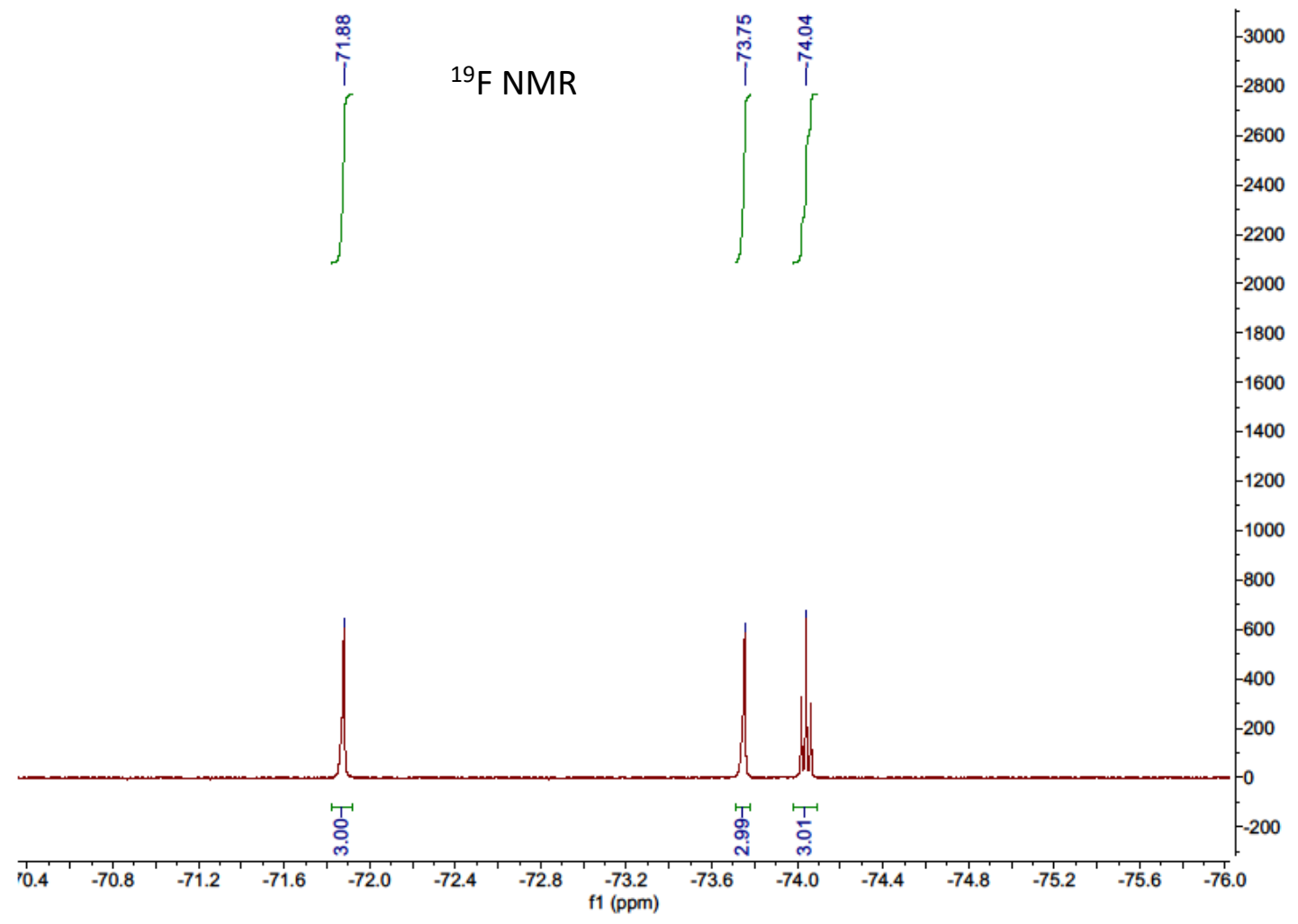



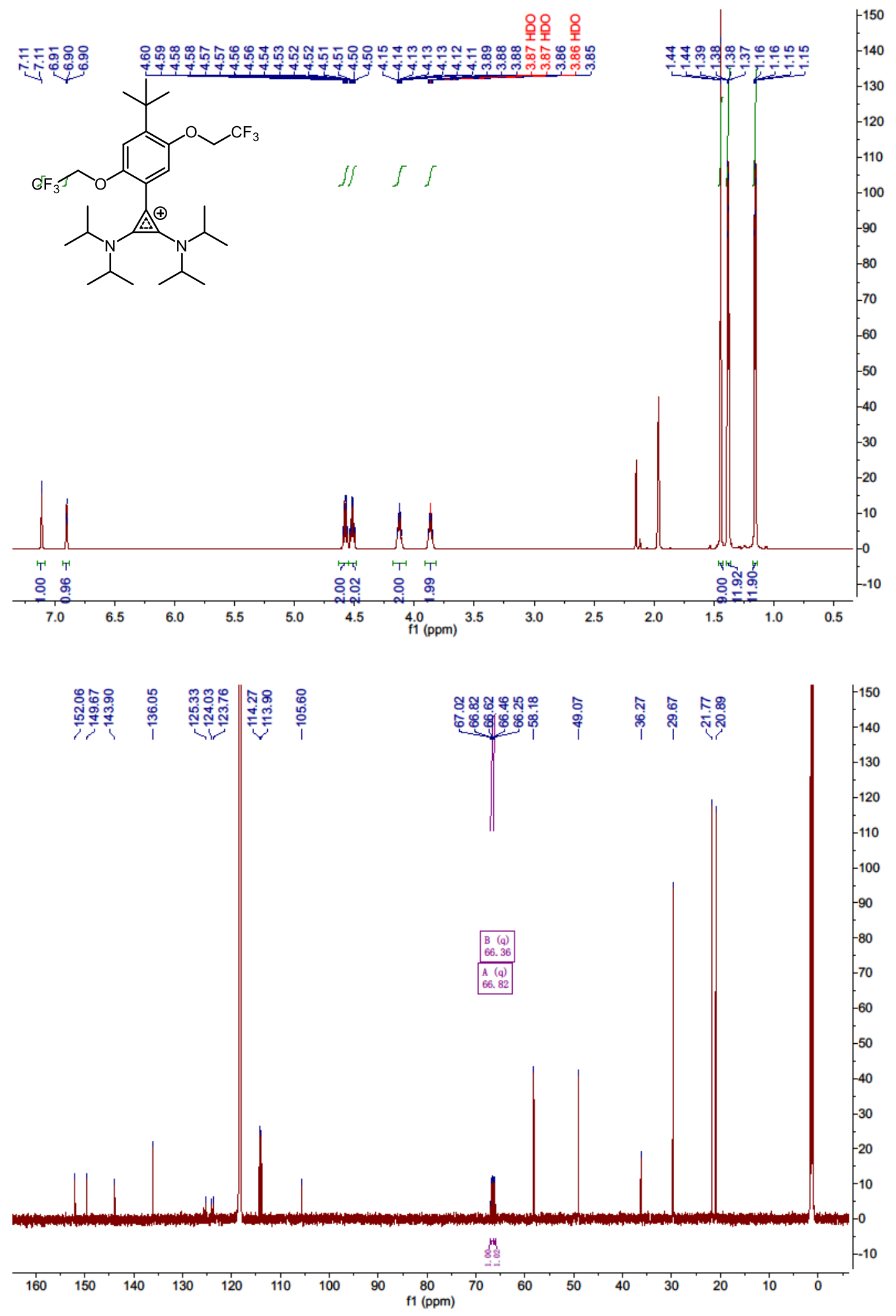


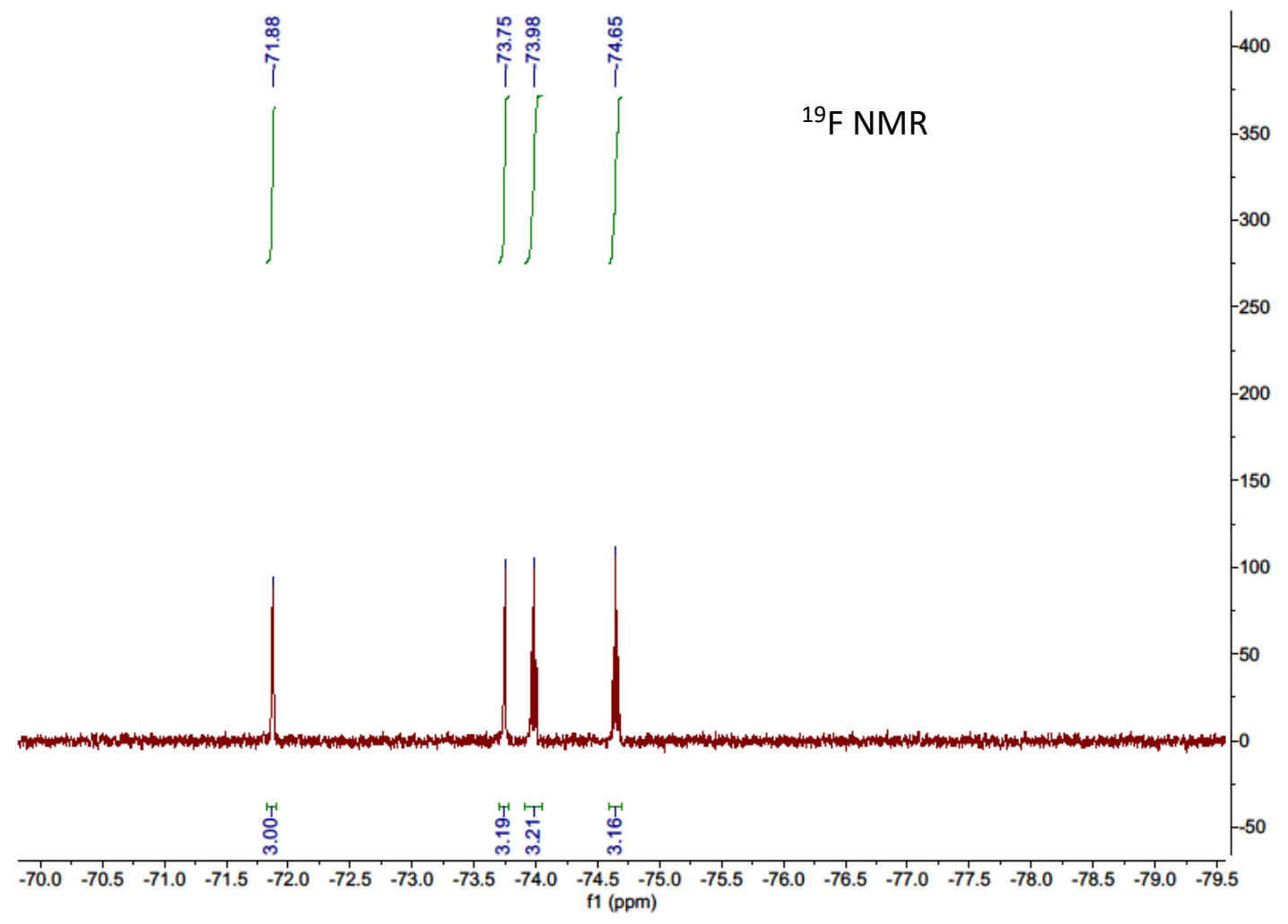



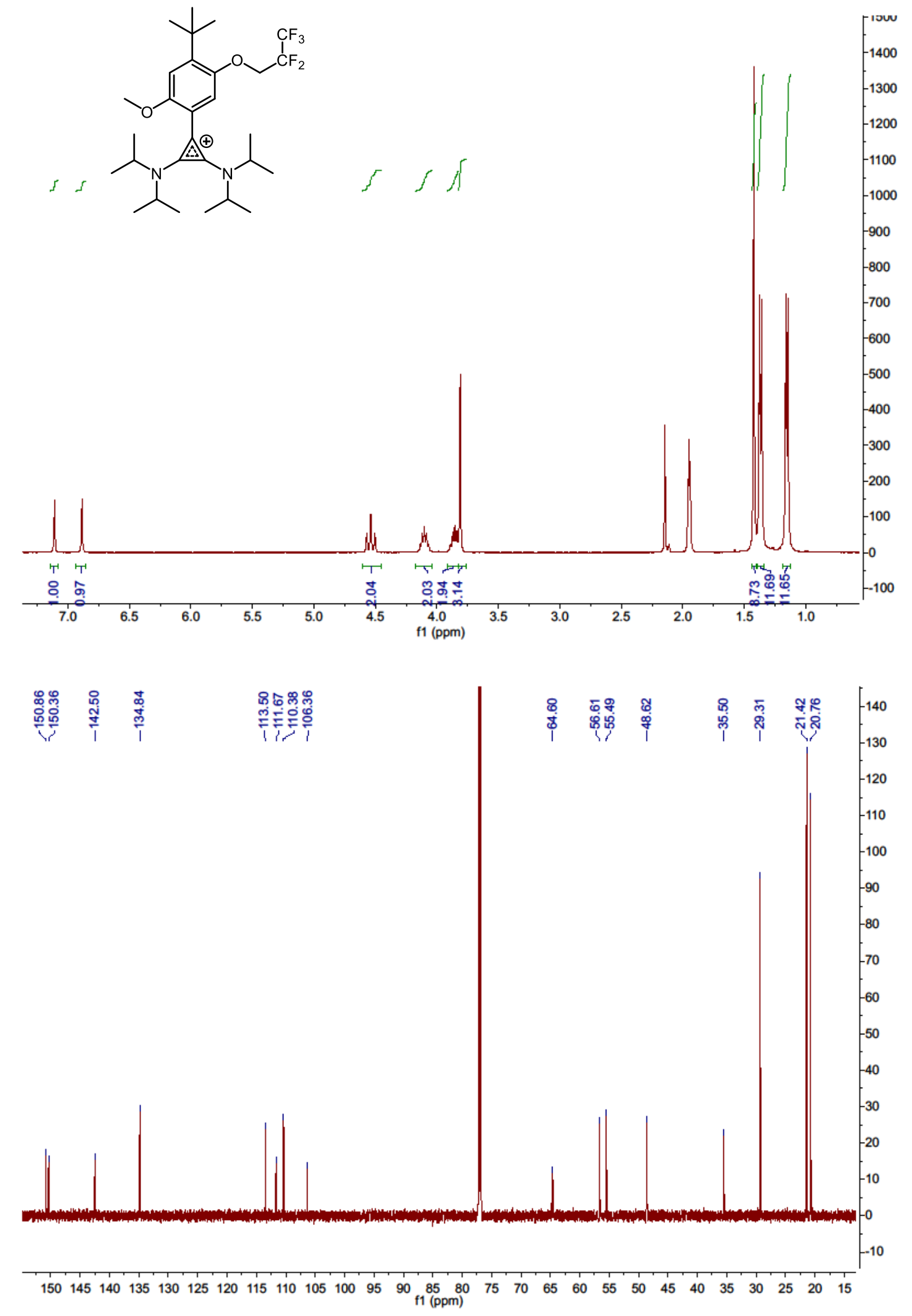


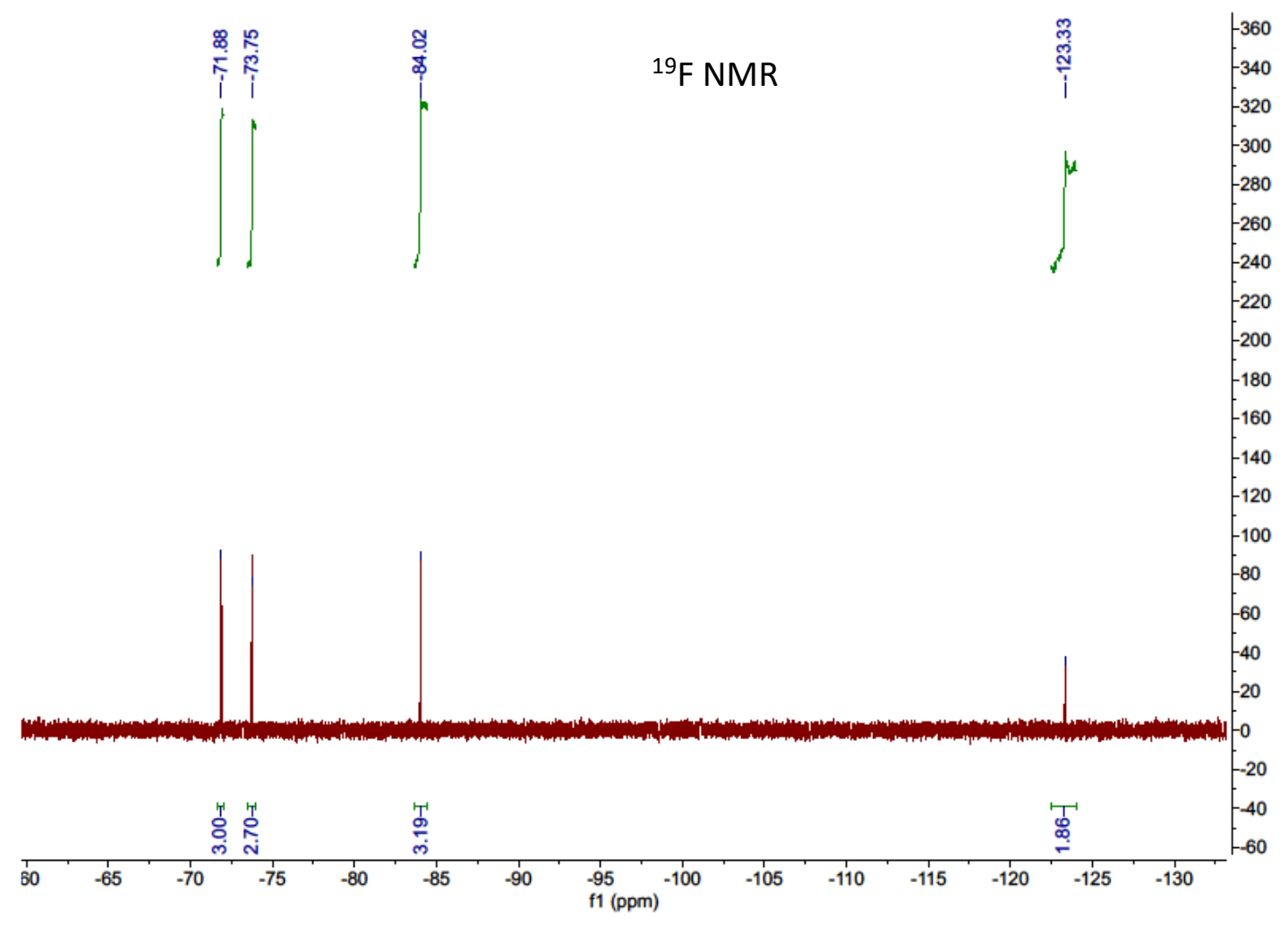




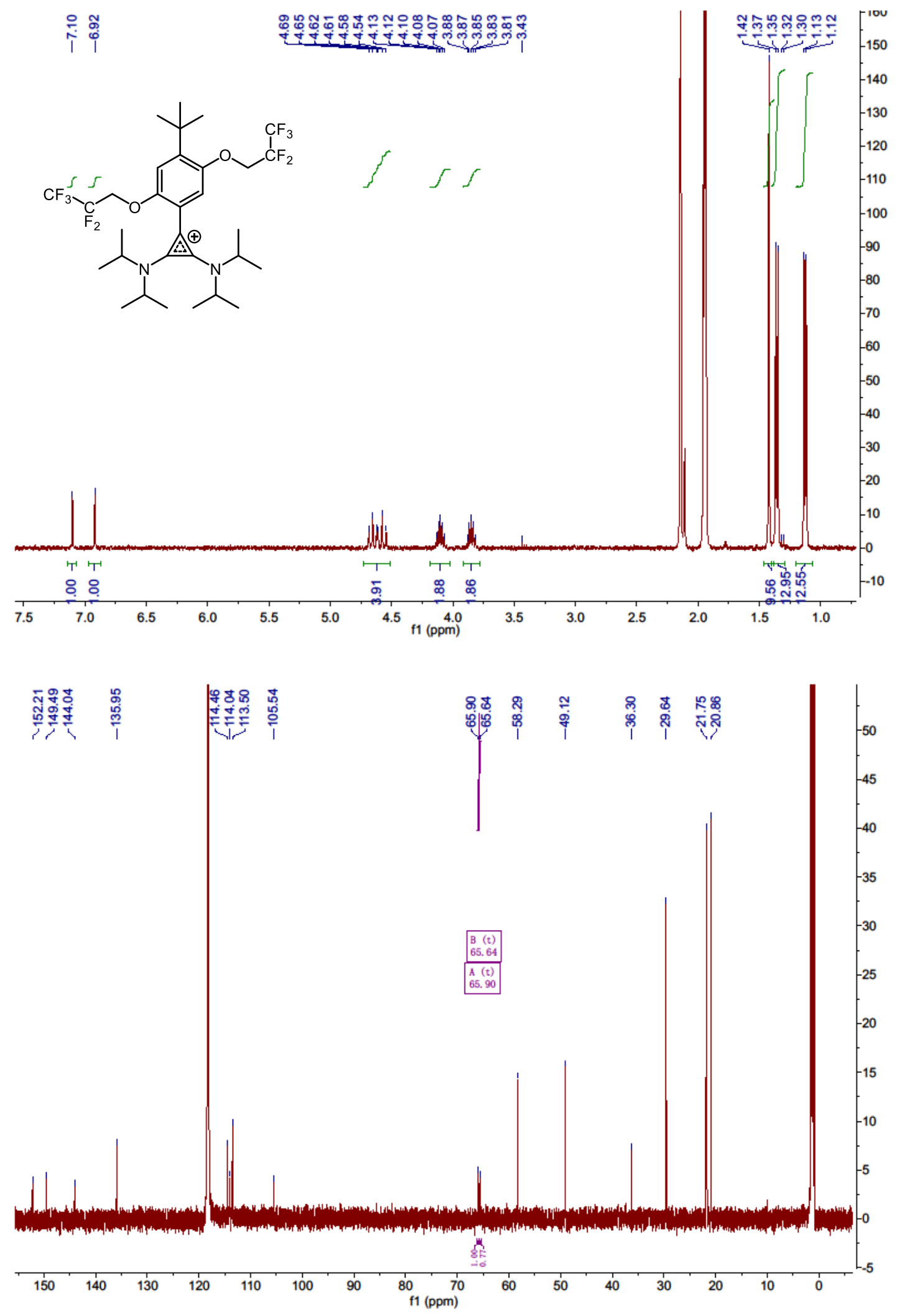




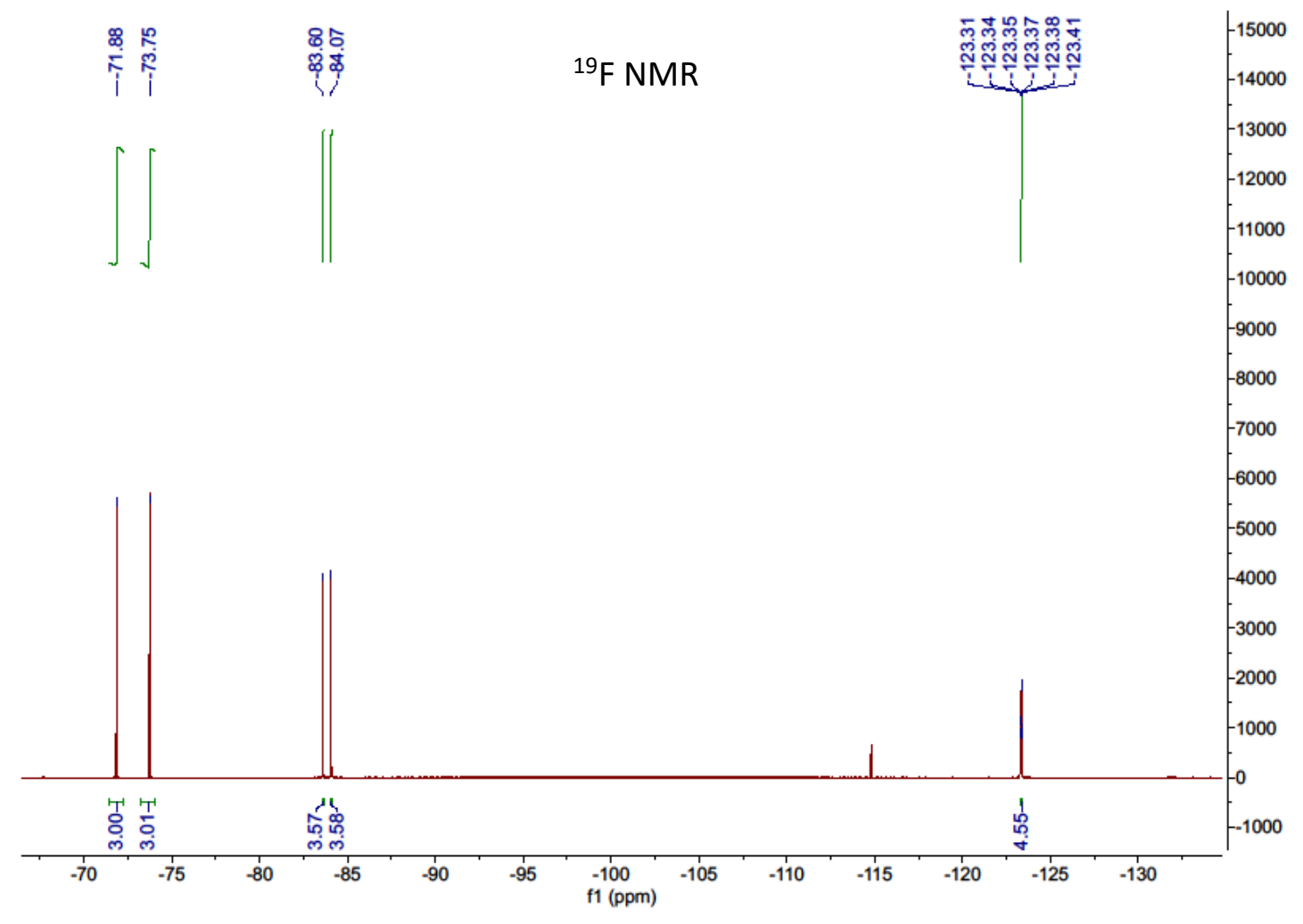




\section{DFT Calculation Methods and Data}

All calculations were done in Spartan (Wavefunction, Inc.). The 6-31G* basis set was used for geometry optimization and $6-311+\mathrm{G}^{* *}$ was used for energy and other calculations at the optimized geometry. All were done in "polar solvent," which uses a conductor-like polarizable continuum model for the solvent with a dielectric constant of 37.22 , very close to that of acetonitrile. As stated in the main text, to obtain an appropriate constant for this set of molecules to convert to a solution-phase oxidation potential versus $\mathrm{Fc}^{+/ 0}$, a calculation was performed on the tris(diethylamino)cyclopropenium cation, which we have previously reported to have an oxidation potential of $+0.82 \mathrm{~V}$ versus $\mathrm{Fc}^{+/ 0}$ in acetonitrile. Its calculated ionization energy of $5.39 \mathrm{eV}$ indicates that subtraction of $4.57 \mathrm{eV}$ from the calculated ionization energies will give solutionphase oxidation potentials versus $\mathrm{Fc}^{+/ 0}$ (in $\mathrm{V}$ ).

The calculated energies of the cations and dication radicals (in hartrees) are given in the following table. The difference between the two gives the ionization energy, which was then converted to an ionization energy in $\mathrm{eV}$. Subtraction of $4.57 \mathrm{~V}$ (determined from the tris(diethylamino)cyclopropenium calculation) gives a solution-phase oxidation potential $\mathrm{vs}^{+} \mathrm{Fe}^{+/ 0}$.

\section{Table S1. Calculated Oxidation Potentials}

\begin{tabular}{cccccc}
$\begin{array}{c}\text { compound } \\
\text { number }\end{array}$ & $\begin{array}{c}\text { monocation } \\
\text { energy (hartrees) }\end{array}$ & $\begin{array}{c}\text { dication radical } \\
\text { energy (hartrees) }\end{array}$ & $\begin{array}{c}\text { IE } \\
\text { (hartrees) }\end{array}$ & IE (eV) & $\begin{array}{c}\text { calculated } \\
E_{1 / 2} \text { (V vs Fc) }\end{array}$ \\
\hline $\mathbf{3 a}^{+}$ & 929.675093 & 929.447039 & 0.228054 & 6.205668616 & 1.6357 \\
$\mathbf{3 b}^{+}$ & 1086.972478 & 1086.749105 & 0.223373 & 6.078292052 & 1.5083 \\
$\mathbf{3 c}^{+}$ & 1044.235448 & 1044.020077 & 0.215371 & 5.860546429 & 1.2905 \\
$\mathbf{3 d}^{+}$ & 1316.08195 & 1315.878596 & 0.203354 & 5.533547036 & 0.9635 \\
$\mathbf{3 e}^{+}$ & 1653.233199 & 1653.023575 & 0.209624 & 5.704162514 & 1.1342 \\
$\mathbf{3 f}^{+}$ & 1990.379359 & 1990.166302 & 0.213057 & 5.79757925 & 1.2276 \\
$\mathbf{3 g}^{+}$ & 1891.090175 & 1890.880605 & 0.20957 & 5.702693098 & 1.1327 \\
$\mathbf{3 h}^{+}$ & 2466.093845 & 2465.880065 & 0.21378 & 5.817253092 & 1.2473 \\
& & & & & \\
$\mathbf{1}^{+}$ & 753.933119 & 753.735044 & 0.198075 & 5.389898055 & 0.8199 \\
$\mathbf{2}^{+}$ & 1136.10204 & 1135.882978 & 0.219062 & 5.960983707 & 1.391
\end{tabular}



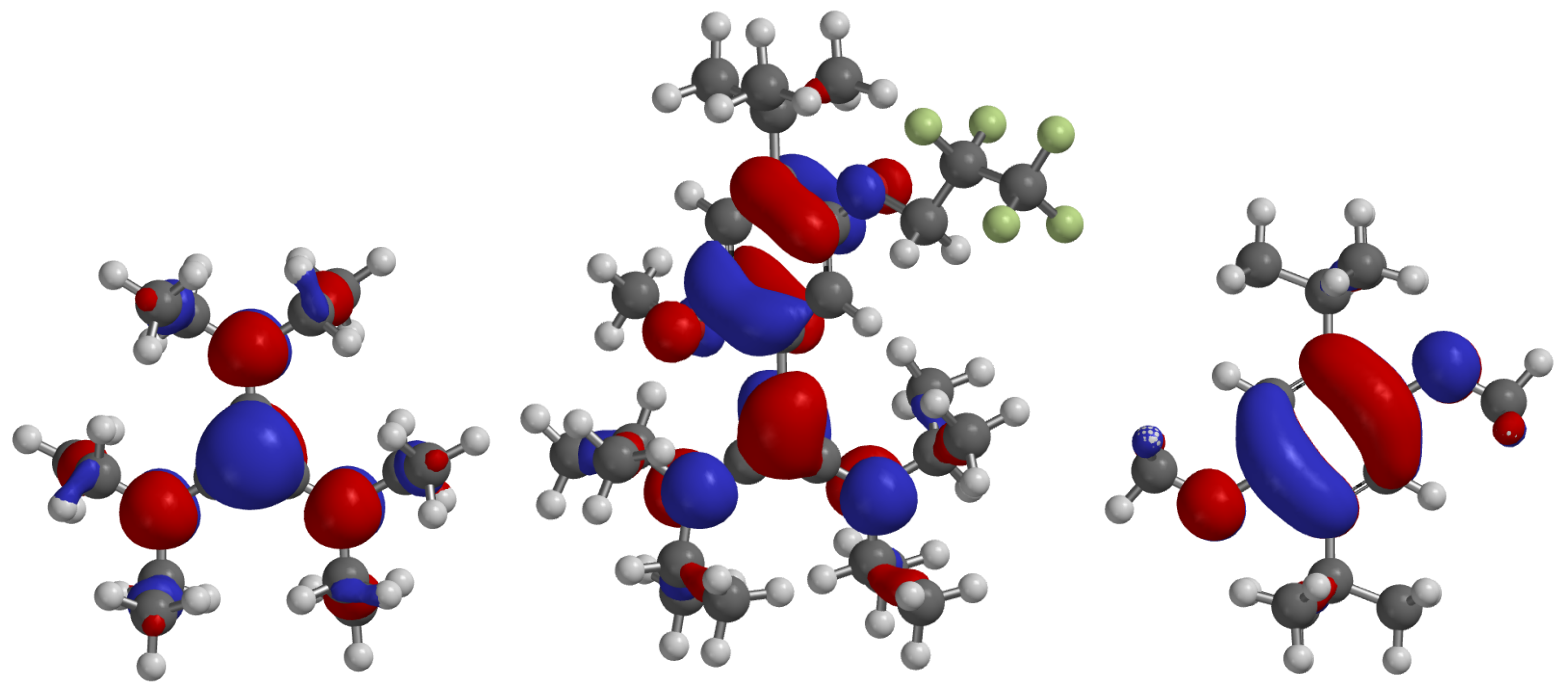

Figure S1. The SOMOs of tris(diethylamino)cyclopropenium dication radical (left), 1,4dimethoxy-2,5-di-tert-butylbenzene radical cation (right), and $\mathbf{3} \mathbf{g}^{\mathbf{2 +}}$ (middle). 


\section{Electrochemistry Experimental Procedures}

General methods and materials. Acetonitrile (anhydrous, 99.8\%) was obtained from Sigma Aldrich and used as received. Potassium hexafluorophosphate ( $\mathrm{KPF}_{6}$; electrochemical grade) was obtained from Sigma Aldrich and dried under high vacuum for $48 \mathrm{~h}$ at $70{ }^{\circ} \mathrm{C}$ before being transferred to a $\mathrm{N}_{2}$-filled glovebox. A $0.50 \mathrm{M}$ stock solution of $\mathrm{KPF}_{6}$ in acetonitrile was prepared in a $\mathrm{N}_{2}$-filled glovebox and dried over $3 \AA$ molecular sieves for at least two days prior to use. The Celgard 2500 membrane was generously provided by the Celgard company and used as received.

Cyclic voltammetry. Cyclic voltammetry (CV) was performed in a $\mathrm{N}_{2}$-filled glovebox with a Biologic VSP multichannel potentiostat/galvanostat using a three-electrode electrochemical cell, consisting of a glassy carbon disk working electrode $\left(0.071 \mathrm{~cm}^{2}, \mathrm{BASi}\right), \mathrm{a} \mathrm{Ag} / \mathrm{Ag}^{+}$reference electrode (BASi) with $0.01 \mathrm{M} \mathrm{AgBF}_{4}$ (Sigma) and $0.5 \mathrm{M} \mathrm{KPF}_{6}$ in acetonitrile, and a platinum wire counter electrode. All experiments were conducted in a $0.50 \mathrm{M} \mathrm{KPF}_{6}$ electrolyte stock solution.

Half-cell cycling. Bulk charge/discharge measurements were carried out in a $\mathrm{N}_{2}$-filled glovebox with a BioLogic VSP galvanostat in a custom glass H-cell with an ultrafine fritted glass separator (P5, Adams and Chittenden). The working and counter electrodes were reticulated vitreous carbon (100 ppi, $70 \mathrm{~cm}^{2}$ surface area, Duocel). A Ag/ $\mathrm{Ag}^{+}$reference electrode was used on the working side of the H-cell. The electrolyte contained $5 \mathrm{mM}$ active species and $0.50 \mathrm{M} \mathrm{KPF}_{6}$ in acetonitrile. The working chamber of the H-cell was loaded with $5.0 \mathrm{~mL}$ of the electrolyte solution, and the counter side was loaded with $5.0 \mathrm{~mL}$ of a solution containing methyl viologen hexafluorophosphate. Both chambers were stirred continuously during cycling at a current of 5 $\mathrm{mA}$. Voltage cutoffs of $+0.3 \mathrm{~V}$ higher than $E_{1 / 2}$ as the upper limit and $+0.5 \mathrm{~V}$ as the lower limit were employed.

Flow cell cycling. Cycling under flow conditions was performed with a zero-gap flow cell comprised of graphite charge collecting plates containing an interdigitated flow field in combination with two layers of non-woven carbon felt electrodes (Sigracet 29AA) on each side. ${ }^{8}$ PTFE gaskets were used to achieve $\sim 20 \%$ compression of the felt. Two Celgard 2500 membranes or separated the two half cells, and the exposed area of the membrane in the gasket window was 
used as the active area $\left(2.55 \mathrm{~cm}^{2}\right)$. After assembly, both sides of the cell were loaded with $6.0 \mathrm{~mL}$ of a mixed solution containing $0.050 \mathrm{M} \quad\left[3^{+}\right]\left[\mathrm{PF}_{6}\right]$ and $0.050 \mathrm{M}$ butyl viologen hexafluorophosphate in $0.50 \mathrm{M} \mathrm{KPF}_{6}$ /acetonitrile. The cell was pretreated by continuously flowing the solution above at $10 \mathrm{~mL} / \mathrm{min}$ for $1 \mathrm{~h}$ without any charging process using a peristaltic pump (Cole-Parmer) with Solve-Flex and PFA tubing. After this step, using the same flow rate, galvanostatic charge/discharge cycling was performed using a BioLogic VSP galvanostat employing a charging current of $+30 \mathrm{~mA} / \mathrm{cm}^{2}$ and a discharging current of $-30 \mathrm{~mA} / \mathrm{cm}^{2}$ with 2.5 $\mathrm{V}$ and $0.5 \mathrm{~V}$ voltage limits. A flow cell with $\left[2^{+}\right]\left[\mathrm{PF}_{6}^{-}\right]$catholyte was set up similarly, except that one Fumasep ${ }^{\circledR}$ FAP-375-PP membrane was used, the supporting electrolyte was $0.50 \mathrm{M}$ $\left[\mathrm{NBu}_{4}\right]\left[\mathrm{PF}_{6}\right]$, charge and discharge currents of $10 \mathrm{~mA} / \mathrm{cm}^{2}$ were used, and the cutoff voltages were $2.65 \mathrm{~V}$ and $0.50 \mathrm{~V}$.

In the symmetrical flow cell test, one side of the cell was loaded with $5.0 \mathrm{~mL}$ of $0.30 \mathrm{M}$ $\left[\mathbf{3 g}^{+}\right]\left[\mathrm{PF}_{6}\right]$ and $0.50 \mathrm{M} \mathrm{KPF}_{6}$ in $\mathrm{CH}_{3} \mathrm{CN}$ and the other side was loaded with $5.0 \mathrm{~mL}$ of $0.30 \mathrm{M}$ $\left[\mathbf{3 g}^{2+}\right]\left[\mathrm{PF}_{6}\right]_{2}$ and $0.50 \mathrm{M} \mathrm{KPF}_{6}$ in $\mathrm{CH}_{3} \mathrm{CN}$. The $\left[\mathbf{3 g}^{2+}\right]\left[\mathrm{PF}_{6}\right]_{2}$ solution was prepared by bulk electrolysis according to a previous method. ${ }^{9}$ One Fumasep ${ }^{\circledR}$ FAP-375-PP membrane was used and charge and discharge currents of $35 \mathrm{~mA} / \mathrm{cm}^{2}$ were used, and the cutoff voltages were $0.8 \mathrm{~V}$ and $-0.8 \mathrm{~V}$.

\section{Determination of the Diffusion Coefficient and Electron Transfer Rate Constant of $\mathbf{3 g}^{+}$.} The diffusion coefficient of $\mathbf{3 g}^{+}$was determined by varying the scan rate of cyclic voltammetry measurements between 20 and $300 \mathrm{mV} / \mathrm{s}$, with the data shown in Table S2. Plotting the cathodic and anodic peak currents versus the square root of the scan rate showed a linear relationship, indicating a transport-limited redox process (Figure S1). The slope of this linear relation was used in the Randles-Sevcik equation (eq 1 ) to determine the diffusion coefficient. ${ }^{10}$

$$
i_{p}=0.4463 n F A C \sqrt{\frac{n F v D}{R T}}
$$

The terms of the equation: $i_{p}$ the peak current in amps, $n$ the number of electrons transferred, $F$ is Faraday's constant, $A$ the area of the electrode in $\mathrm{cm}^{2}, C$ the concentration of redox active species in $\mathrm{mol} \cdot \mathrm{cm}^{-3}, D$ the diffusion coefficient in $\mathrm{cm}^{2} \cdot \mathrm{s}^{-1}, v$ the scan rate in $\mathrm{V} \mathrm{s}^{-1}, R$ the ideal gas constant 
$\left(8.314 \mathrm{~J} \cdot \mathrm{mol}^{-1} \cdot \mathrm{K}^{-1}\right)$, and $T$ the temperature in $\mathrm{K}$.

Table S2. Cyclic Voltammetry Peak Currents Versus Scan Rate for $\mathbf{3 g ^ { + }}$

$\begin{array}{ccc}\begin{array}{c}\text { Scan rate } \\ (\mathrm{mV} / \mathrm{s})\end{array} & \begin{array}{c}\text { Anodic peak } \\ (\mathrm{mA})\end{array} & \begin{array}{c}\text { Cathodic peak } \\ (\mathrm{mA})\end{array} \\ 20 & 0.03885 & -0.03278 \\ 30 & 0.0463 & -0.041 \\ 50 & 0.058 & -0.05144 \\ 100 & 0.078 & -0.072 \\ 150 & 0.09905 & -0.0881 \\ 200 & 0.112 & -0.1004 \\ 300 & 0.134 & -0.1214\end{array}$

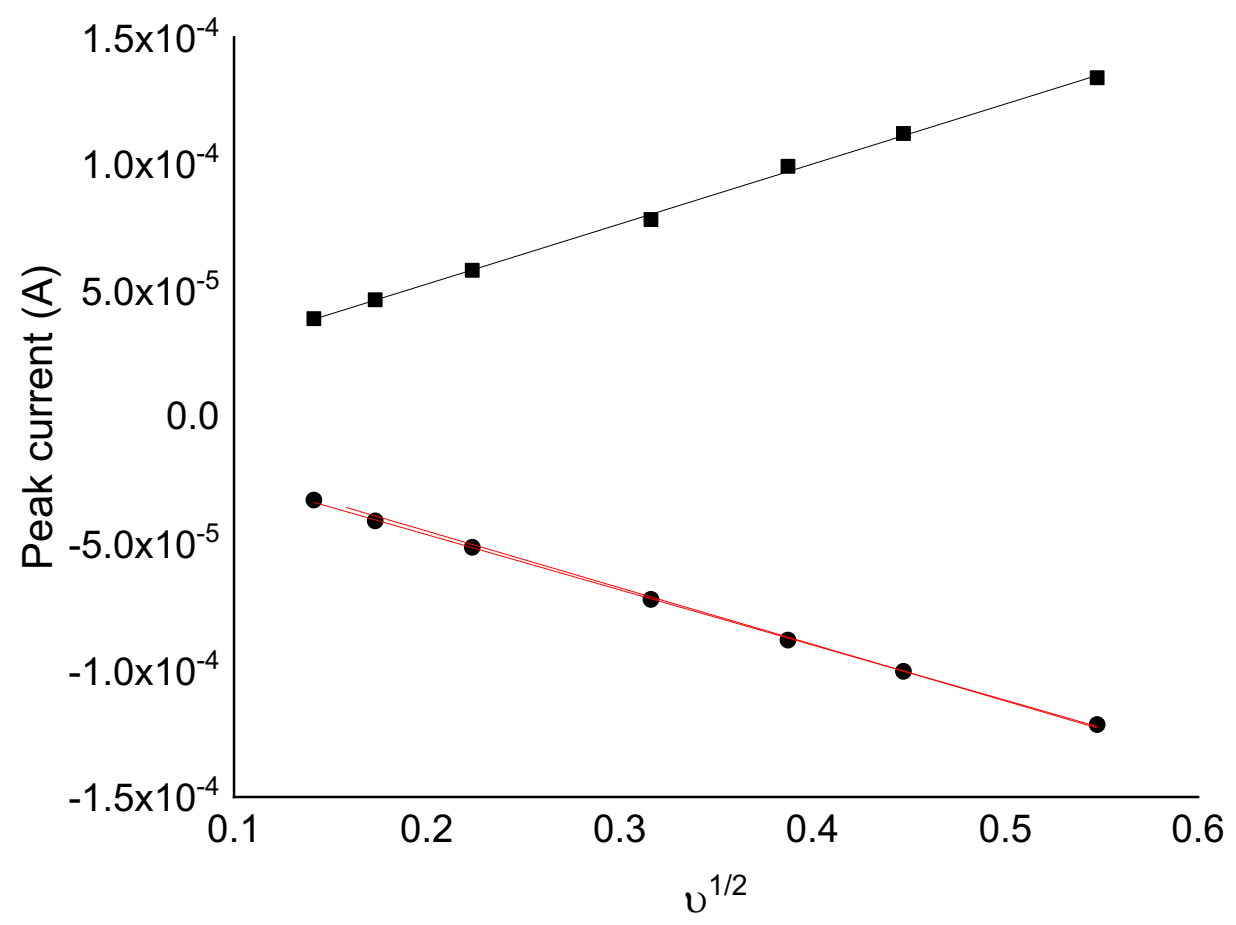

Figure S2. Peak current vs square root of the scan rate and linear fits used to determine diffusion coefficients.

The heterogeneous electron transfer rate constant was determined following the Nicholson 
method. ${ }^{11}$ At each scan rate, the separation between the potential of the anodic and cathodic peaks, $\Delta E_{\mathrm{p}}$, can be converted to a dimensionless number $\Psi$ using a "working curve" of the Nicholson paper. The data is given in Table S3. Plotting the resulting values of $\Psi$ versus the inverse square root of the scan rate (Figure S2) gave a relationship from which the slope was used to determine the heterogeneous electron transfer rate constant $k_{0}$ according to eq 2 ,

$$
\psi=\frac{\gamma^{\alpha} k_{0}}{\sqrt{\pi a D_{0}}}
$$

where $\Psi$ is the Nicolson dimensionless number, $\gamma=D_{o} / D_{r}$, where $D_{o}$ and $D_{r}$ are the diffusion coefficients $\left(\mathrm{cm}^{2} \cdot \mathrm{s}^{-1}\right)$ of the oxidized and reduced species, respectively, $\alpha$ is the charge transfer coefficient (assumed to be 0.5 ), $k_{0}$ is the rate constant in $\mathrm{cm} \cdot \mathrm{s}^{-1}, a=n F v / R T$, where $n$ is the number of electrons transferred in redox reaction, $F$ is the Faraday constant $\left(96485 \mathrm{C} \mathrm{mol}^{-1}\right)$, $v$ is the scan rate in $\mathrm{V} \cdot \mathrm{s}^{-1}, R$ is the ideal gas constant $\left(8.314 \mathrm{~J} \mathrm{~mol}^{-1} \mathrm{~K}^{-1}\right), T$ is the temperature in $\mathrm{K}$.

Table S3. Cyclic Voltammetry Peak Separation Versus Scan Rate for $\mathbf{3 g}^{+}$Nicholson Analysis
$\begin{array}{ccccccc}\text { Scan rate } & \text { Scan rate } & (\text { scan rate })^{\wedge}-0.5 & \text { anodic peak } & \text { cathodic peak } & \begin{array}{c}\text { Peak } \\ \text { separation }\end{array} & \text { Psi } \\ \mathrm{mV} / \mathrm{s} & \mathrm{V} / \mathrm{s} & (\mathrm{V} / \mathrm{s})^{\wedge}-0.5 & \mathrm{mV} & \mathrm{mV} & \mathrm{mV} & \\ & & & & & & \\ 20 & 0.02 & 7.071 & 1303 & 1191 & 112 & 0.42091 \\ 30 & 0.03 & 5.774 & 1308 & 1189 & 119 & 0.36361 \\ 50 & 0.05 & 4.472 & 1318 & 1184 & 134 & 0.27383 \\ 70 & 0.07 & 3.780 & 1325 & 1175 & 150 & 0.2127 \\ 100 & 0.1 & 3.162 & 1332 & 1183 & 149 & 0.21461 \\ 150 & 0.15 & 2.582 & 1326 & 1158 & 168 & 0.16686\end{array}$




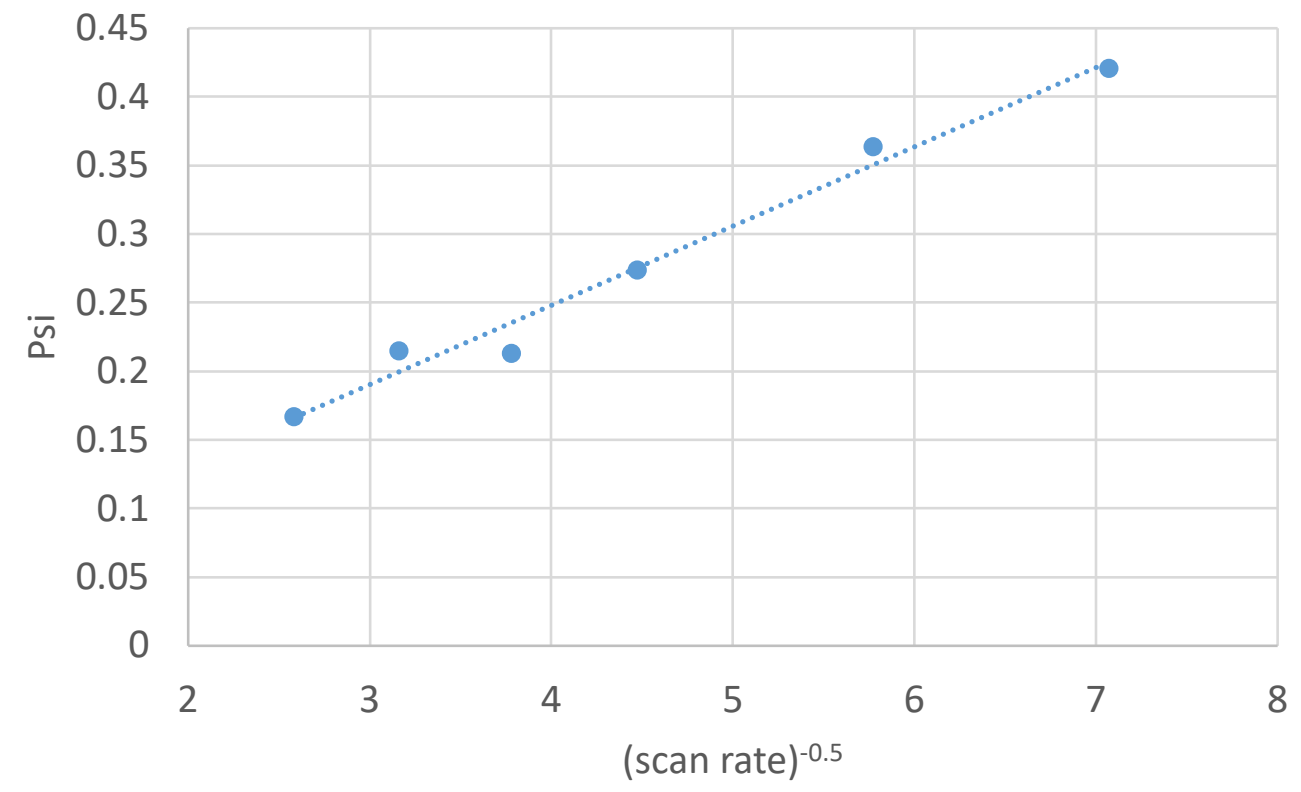

Figure S3. Plot of $\Psi$ versus (scan rate) ) $^{-0.5}$. The slope was used to determine the heterogeneous electron transfer rate constant.

\section{Additional Electrochemical Data}

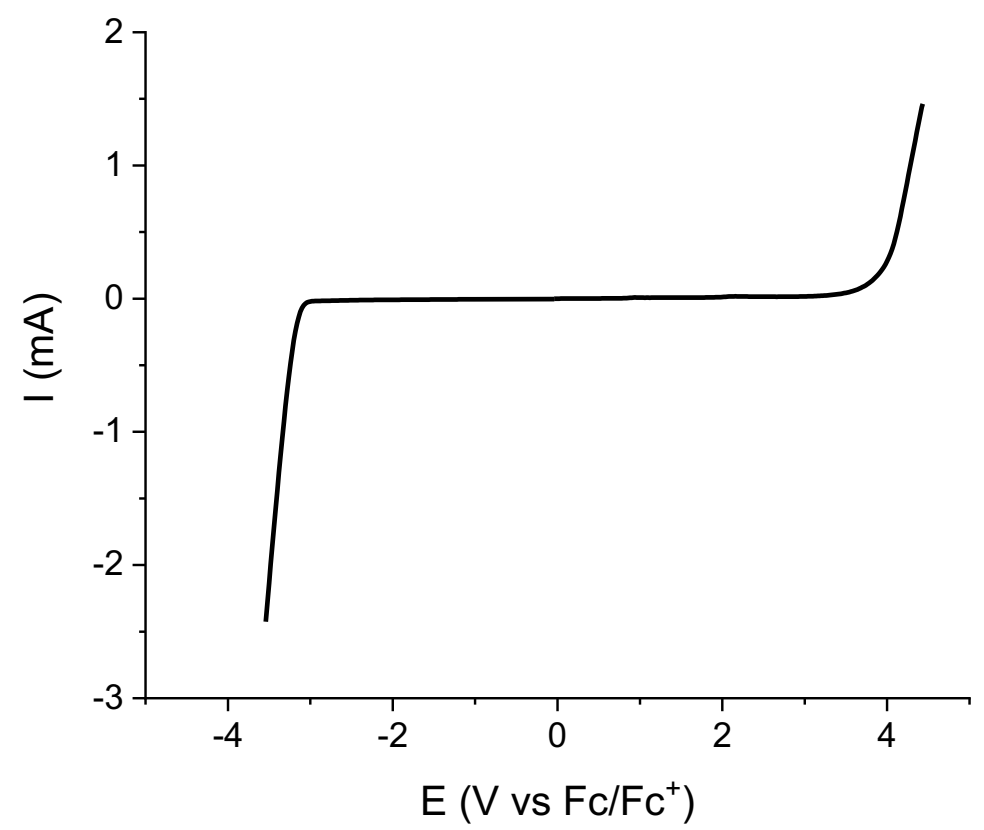

Figure S4. Electrochemical stability window of $0.50 \mathrm{M} \mathrm{KPF}_{6} \mathrm{MeCN}$ solution 


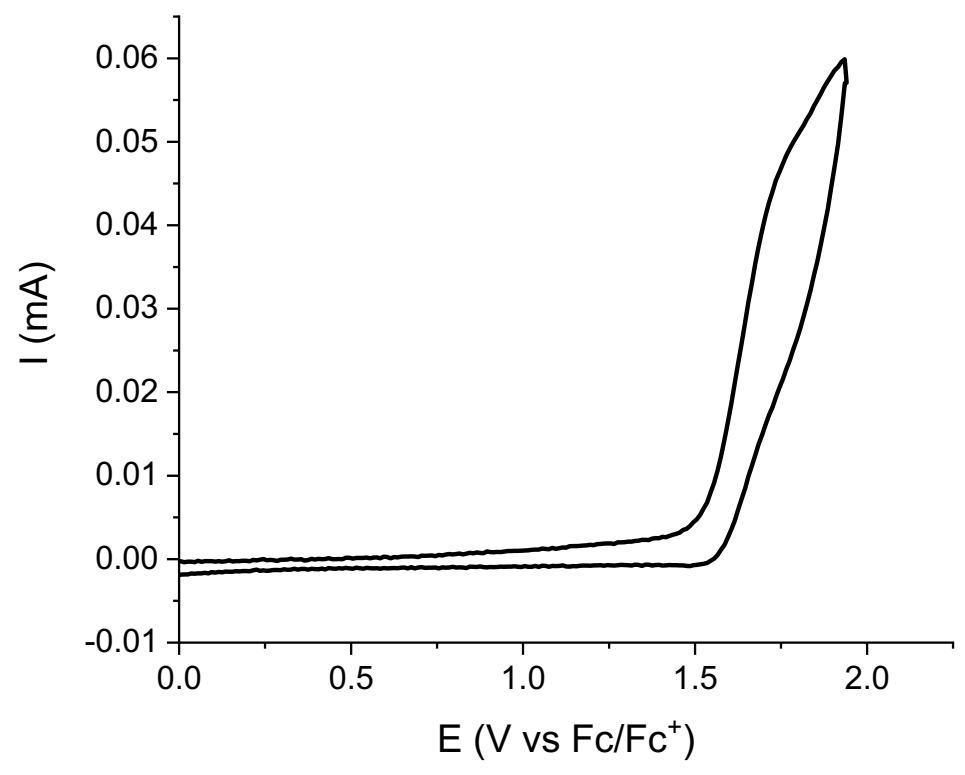

Figure S5. CV of $\left[\mathbf{3 a}^{+}\right]\left[\mathrm{PF}_{6}\right]$ with lower potential cut off $\left(\sim 2 \mathrm{~V}\right.$ vs Fc/Fc $\left.\mathrm{Fc}^{+}\right)$
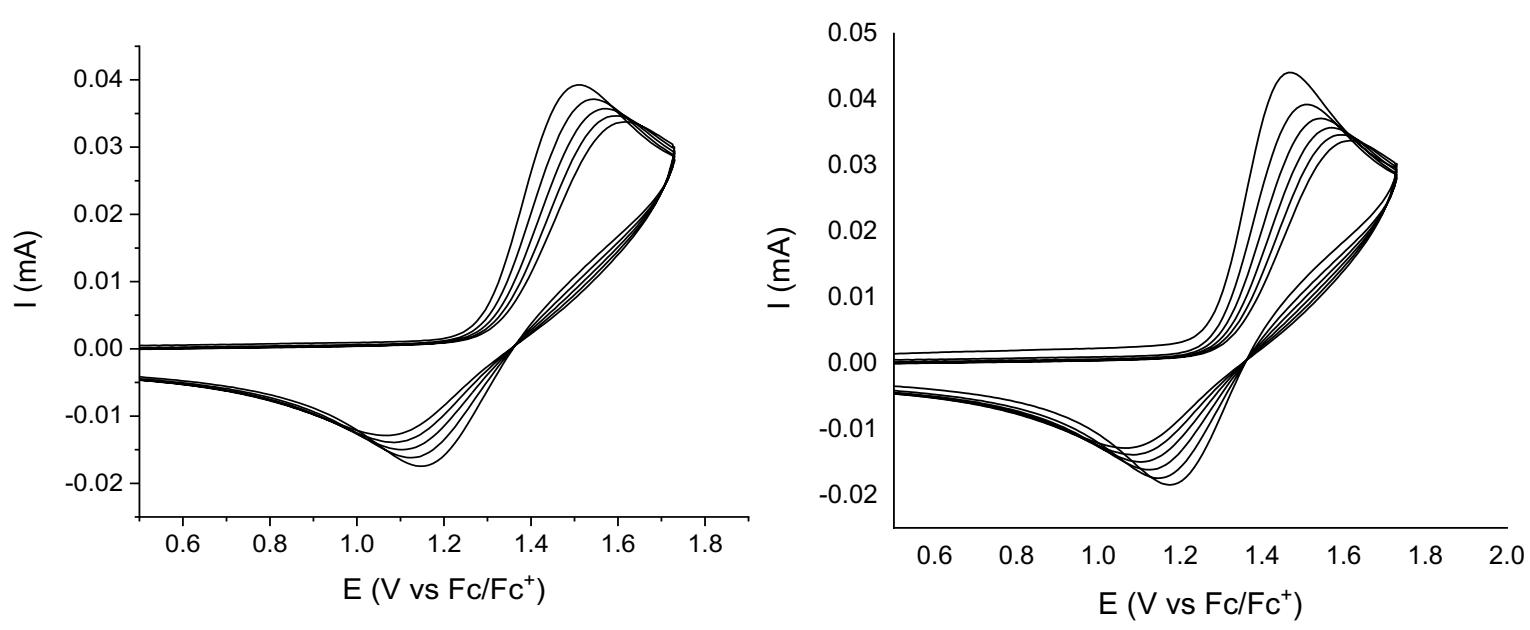

Figure S6. Five cycles (\#2-6) of cyclic voltammograms of $\left[\mathbf{3 f}^{+}\right]\left[\mathrm{PF}_{6}\right]$ (left) and then another six cycles after cleaning the electrode (right) (both in $0.50 \mathrm{M} \mathrm{KPF}_{6} \mathrm{MeCN}$ solution, $100 \mathrm{mV} / \mathrm{s}$ scan rate). 

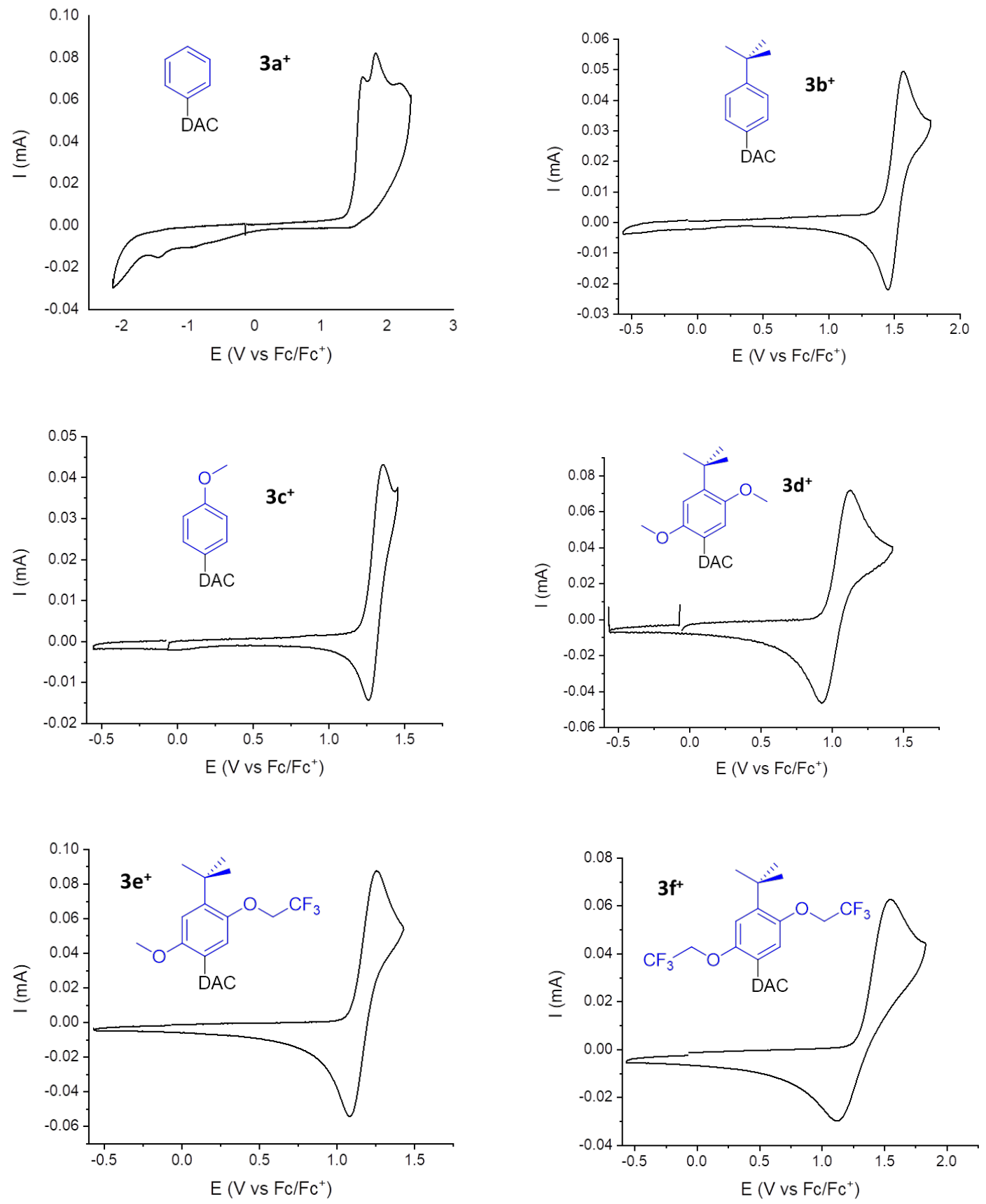

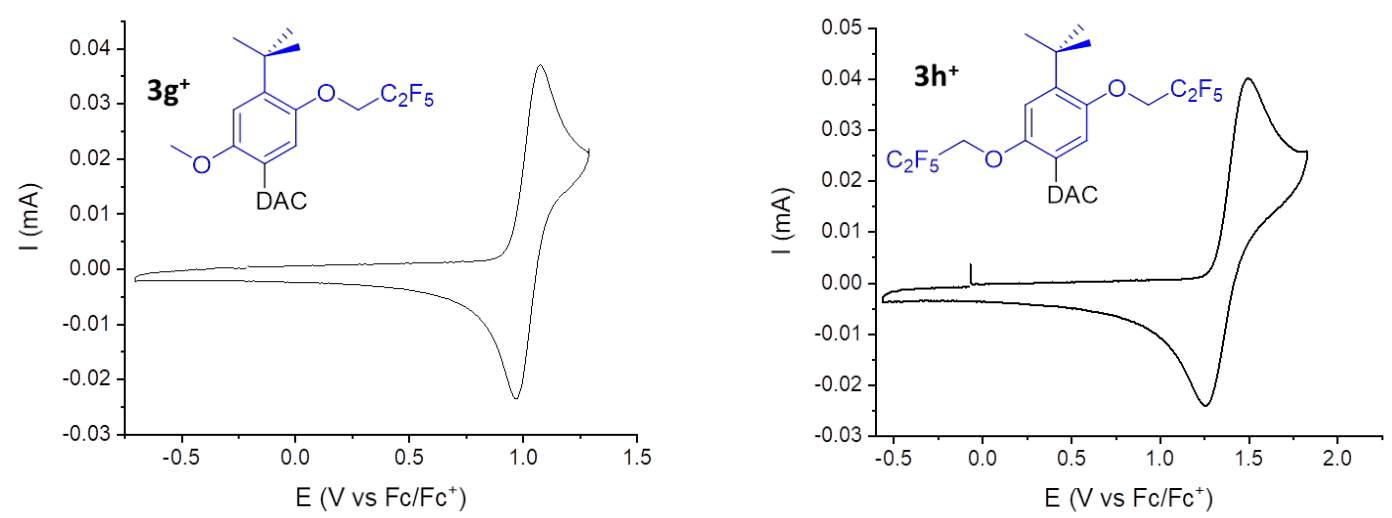

Figure S7. Full CVs of all DAC-arenes discussed in the paper.

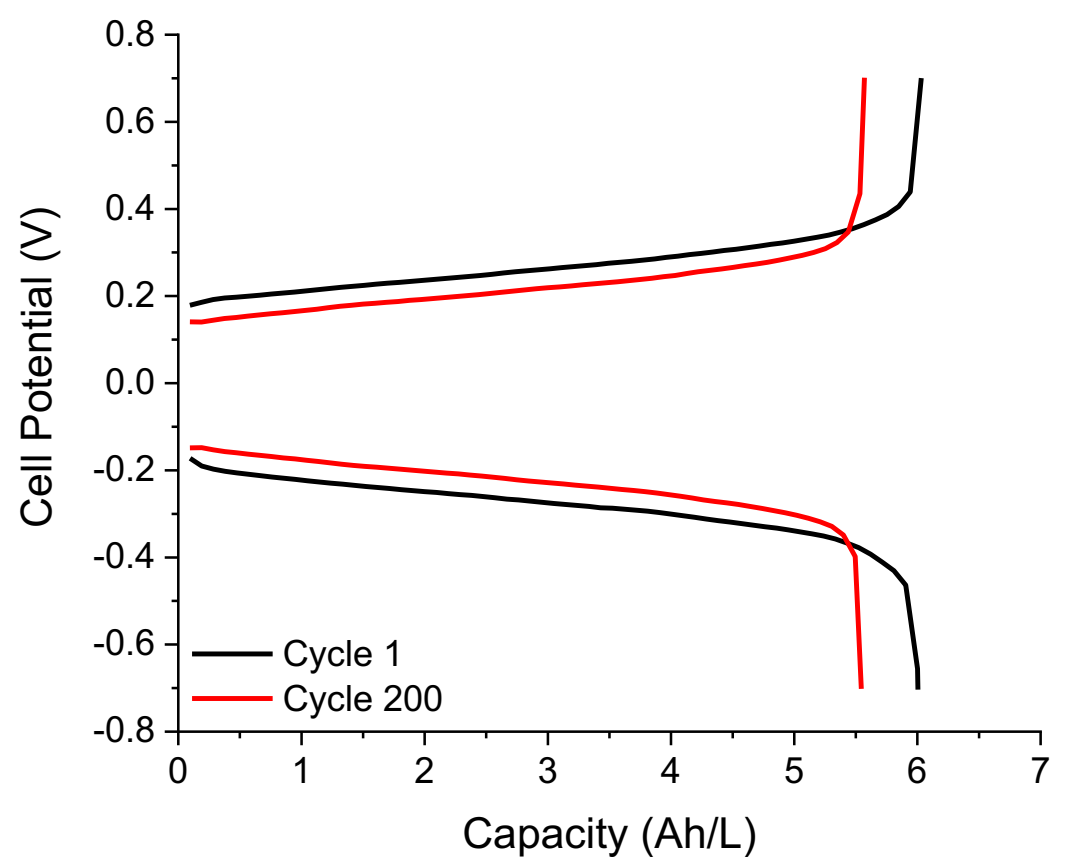

Figure S8. First and last charge-discharge curves from cycling of a $0.30 \mathrm{M}$ solution of $\mathbf{3 g}^{+} / \mathbf{3 g}^{\mathbf{2 +}}$ in $\mathrm{CH}_{3} \mathrm{CN} / 0.50 \mathrm{M} \mathrm{KPF}_{6}$ in a symmetric flow cell. 


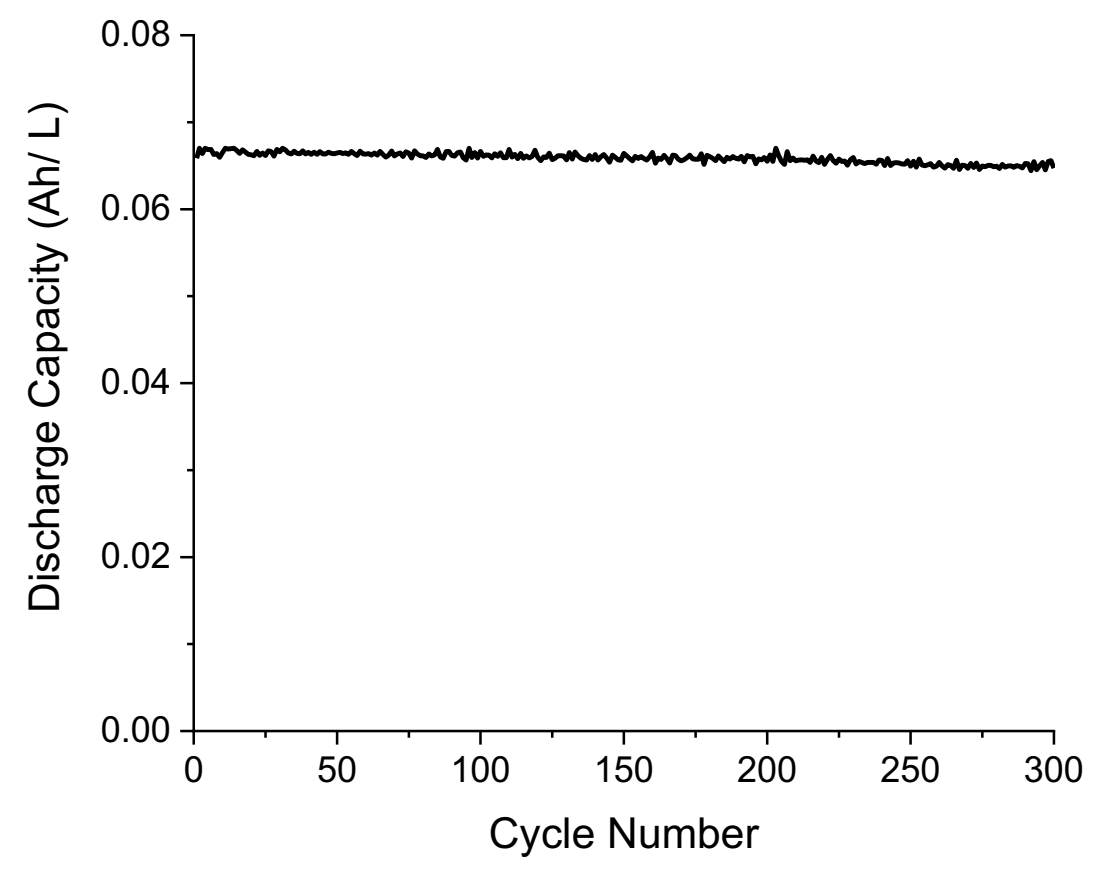

Figure S9. H-cell bulk charge-discharge cycling data for 1,4-di-tert-butyl-2,5-bis(2methoxyethoxy)benzene.

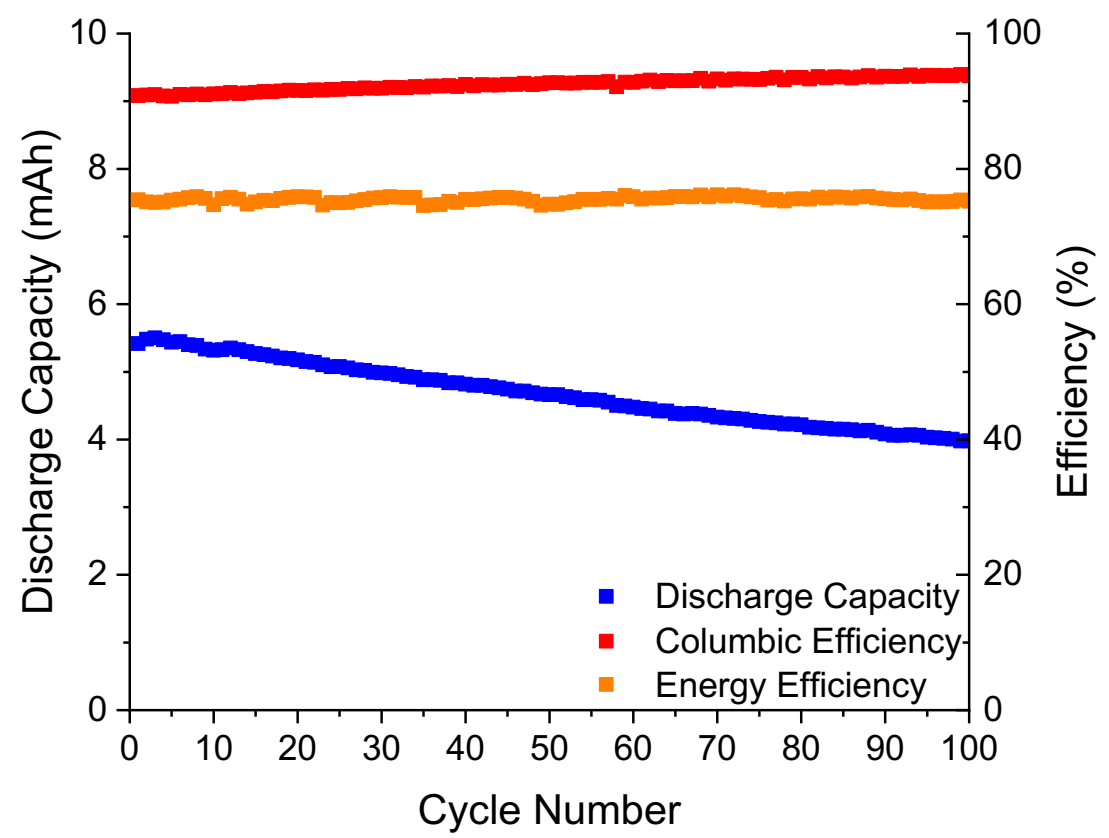

Figure S10. Discharge capacity, coulombic efficiency, and energy efficiency of flow cell cycling of $50 \mathrm{mM}\left[\mathbf{3 g}^{+}\right]\left[\mathrm{PF}_{6}\right]$ and $50 \mathrm{mM}$ butyl viologen in $0.50 \mathrm{M} \mathrm{KPF}_{6}-\mathrm{MeCN}$ solution using two Celgard 2500 membrane 


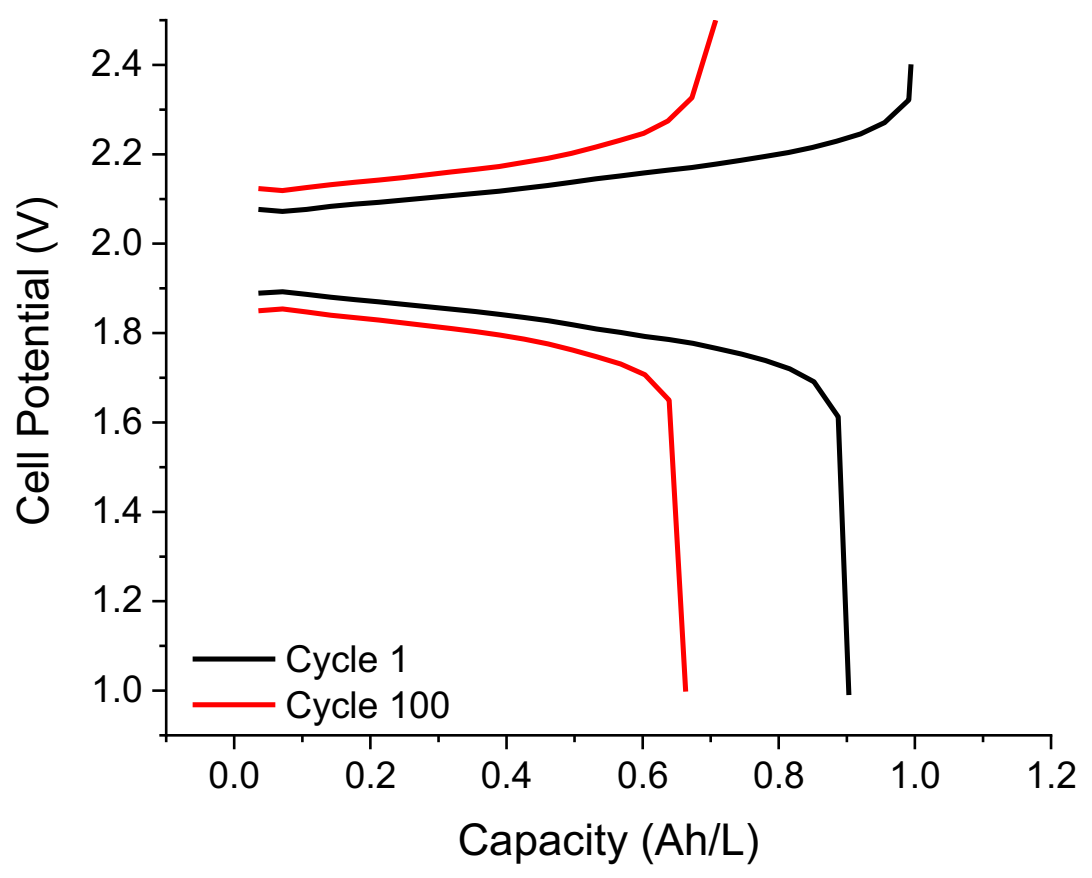

Figure S11. First and last charge-discharge curves from flow cell cycling of $50 \mathrm{mM}\left[\mathbf{3 g}^{+}\right]\left[\mathrm{PF}_{6}\right]$ and $50 \mathrm{mM}$ butyl viologen in $0.50 \mathrm{M} \mathrm{KPF}_{6}-\mathrm{MeCN}$ solution.

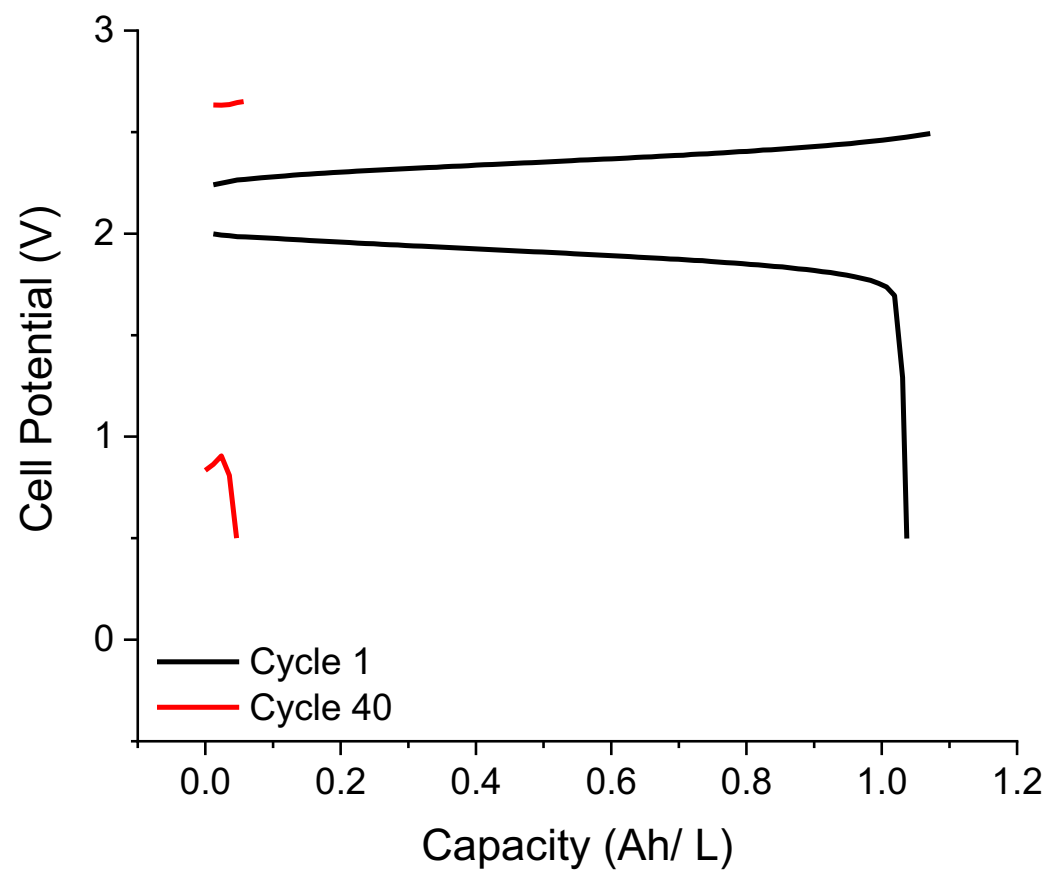

Figure S12. First and last charge-discharge curves from flow cell cycling of $50 \mathrm{mM}\left[\mathbf{2}^{+}\right]\left[\mathrm{PF}_{6}\right]$ and $50 \mathrm{mM}$ butyl viologen in $0.50 \mathrm{M}\left[\mathrm{NBu}_{4}\right]\left[\mathrm{PF}_{6}\right]-\mathrm{MeCN}$ solution. 
The coulombic efficiency increases slightly during the cycling, from an initial $91 \%$ to $94 \%$ at the $100^{\text {th }}$ cycle. The imperfect coulombic efficiency may be due to crossover of charged species from the catholyte to the anolyte chamber (and vice versa) through the porous Celgard membrane. The energy efficiency of approximately $76 \%$ is mainly due to the difference in charge and discharge voltage, which is expected at the high charge and discharge currents used.

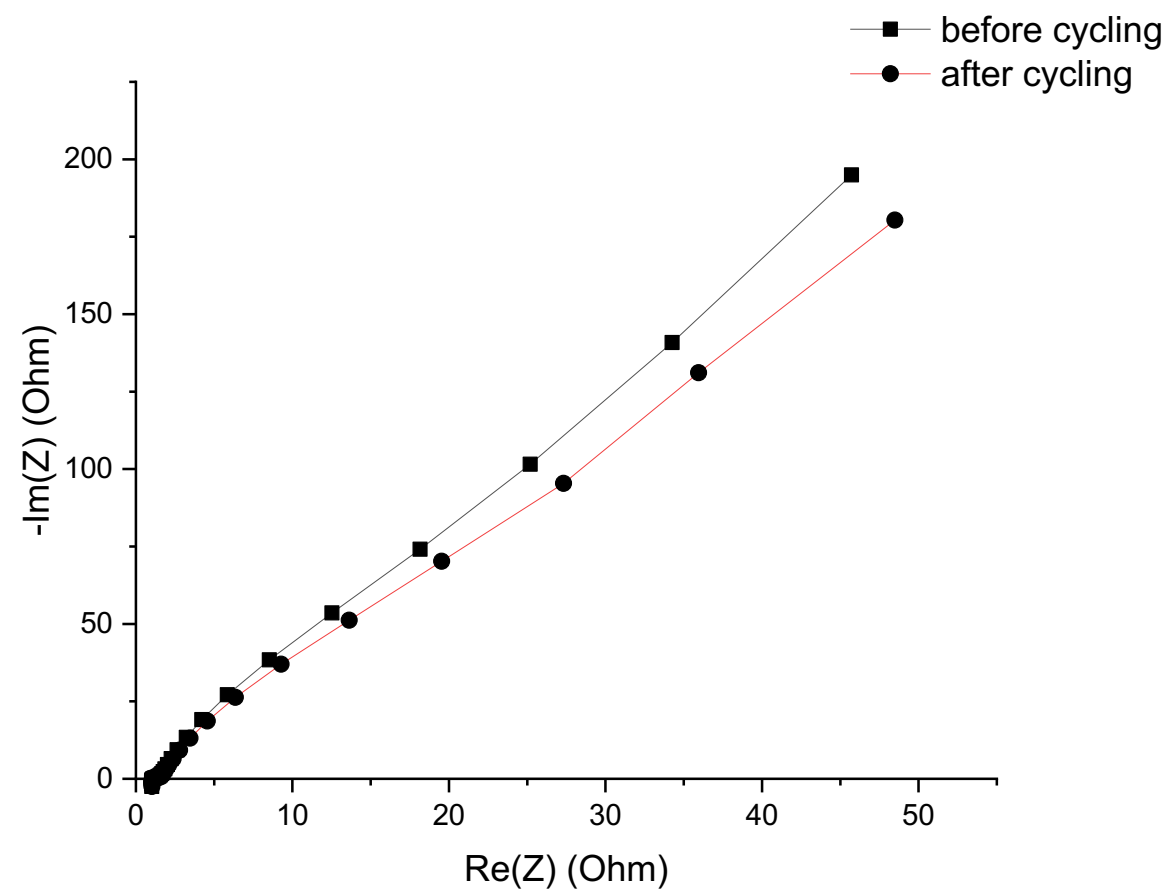

Figure S13. Nyquist plot from electrochemical impedance spectroscopy measurements on the $\mathbf{3} \mathbf{g}^{+}$-butyl viologen flow battery before and after cycling. 


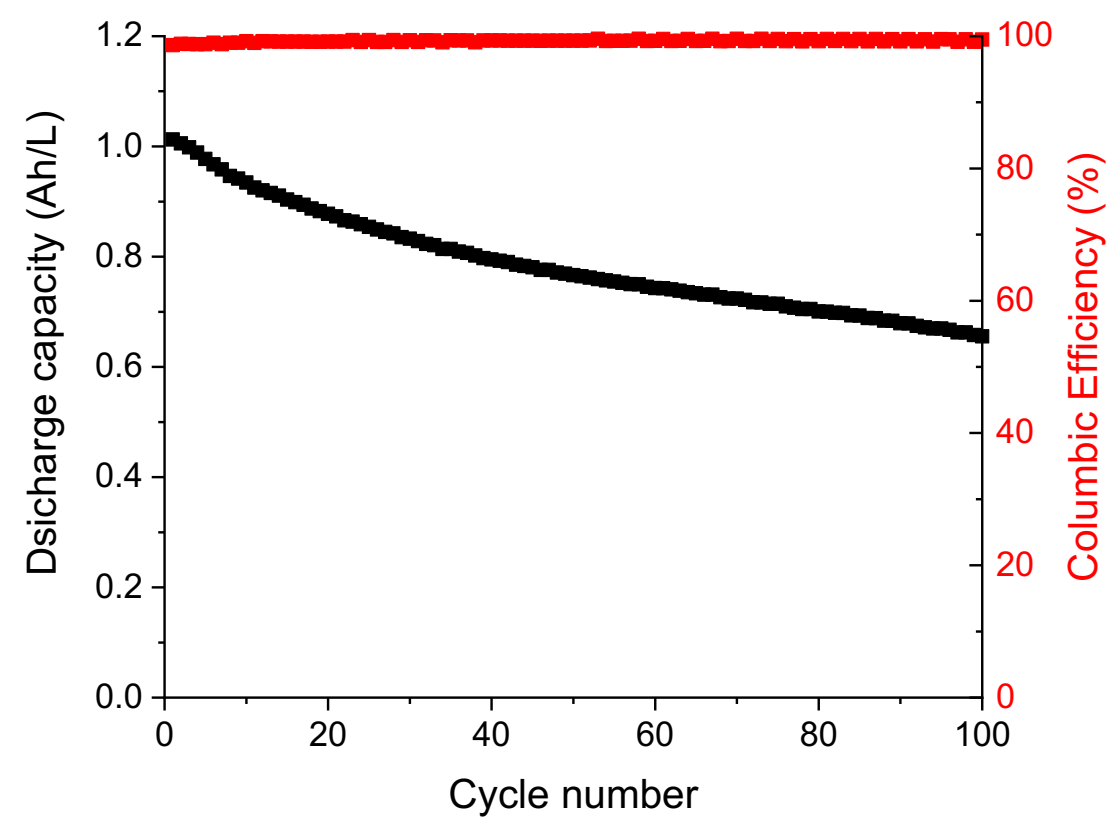

Figure S14. Discharge capacity and coulombic efficiency of flow cell cycling of $50 \mathrm{mM}$ $\left[\mathbf{3 g}^{+}\right]\left[\mathrm{PF}_{6}\right]$ and $50 \mathrm{mM}$ butyl viologen in $0.50 \mathrm{M} \mathrm{KPF}_{6}-\mathrm{MeCN}$ solution using one Fumasep ${ }^{\circledR}$ FAP375-PP membrane.

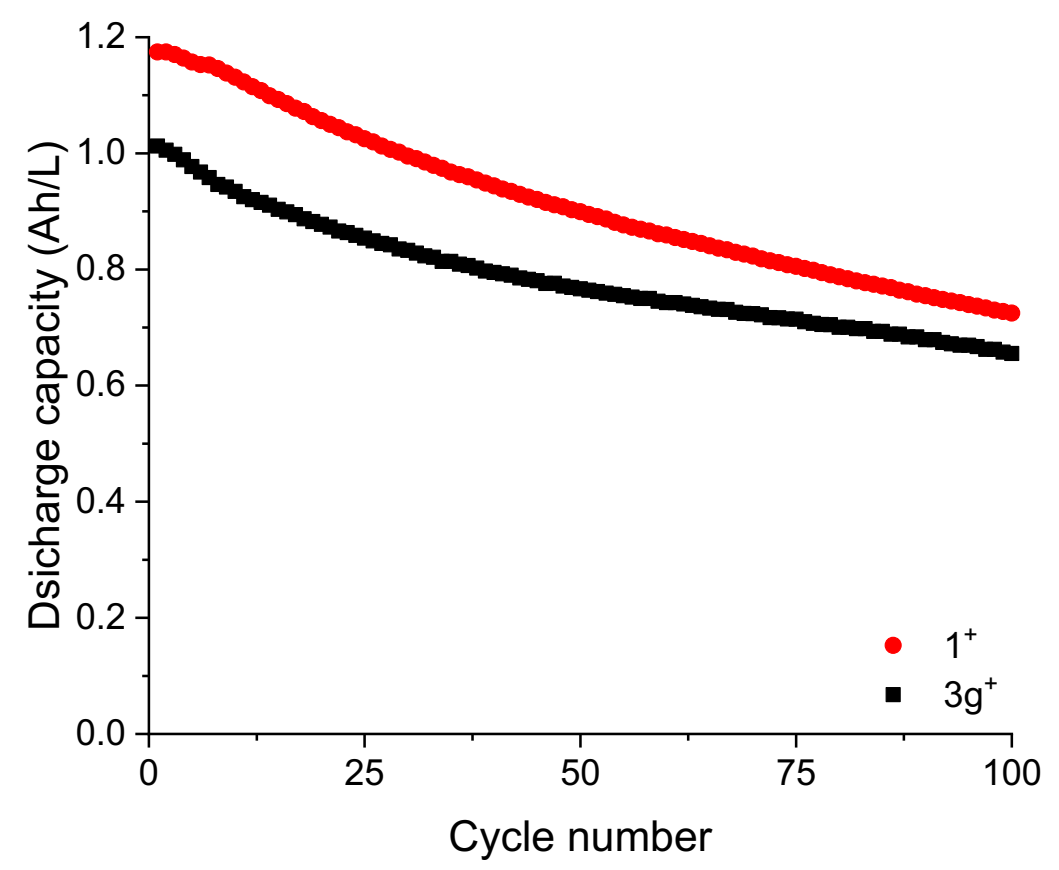

Figure S15. Discharge capacity of flow cell cycling of $50 \mathrm{mM}\left[\mathbf{3 g}^{+}\right]\left[\mathrm{PF}_{6}\right]$ and $50 \mathrm{mM}$ butyl viologen (black), and $50 \mathrm{mM}\left[1^{+}\right]\left[\mathrm{PF}_{6}\right]\left(\mathrm{N}\left({ }^{i} \mathrm{Pr}\right)_{2}, \mathrm{~N}\left({ }^{\mathrm{i} P r}\right)_{2}, \mathrm{~N}(\mathrm{Bu}, \mathrm{Et})\right.$ version) and $50 \mathrm{mM}$ butyl viologen (red) both in $0.50 \mathrm{M} \mathrm{KPF}_{6}-\mathrm{MeCN}_{\mathrm{N}}$ solution using one Fumasep ${ }^{\circledR}$ FAP-375-PP membrane. 

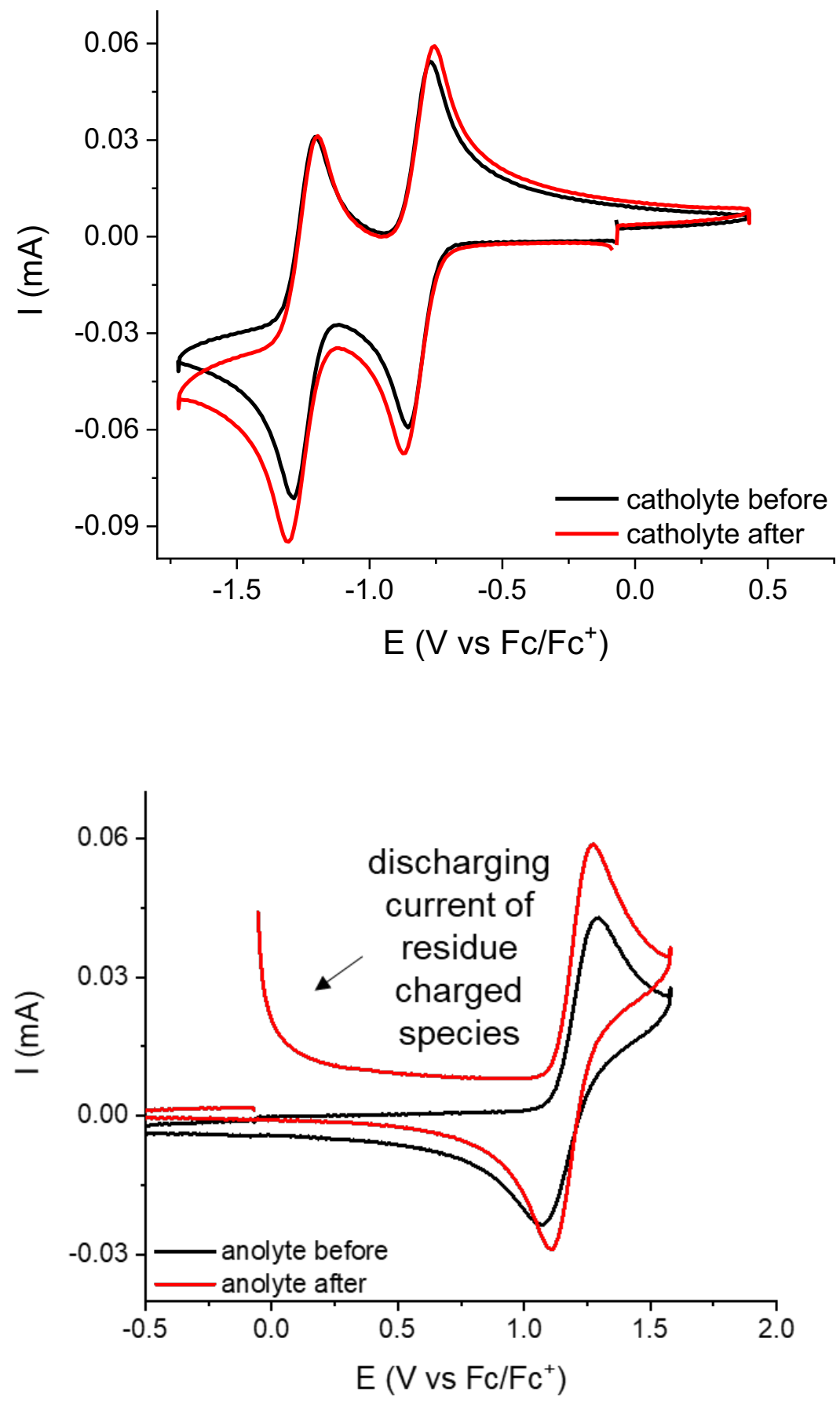

Figure S16. Cyclic voltammograms (of the opposite negative or positive potential region) of the anolyte and catholyte solutions before and after cycling the flow battery of $50 \mathrm{mM}\left[\mathbf{3 g}^{+}\right]\left[\mathrm{PF}_{6}\right]$ and $50 \mathrm{mM}$ butyl viologen in $0.50 \mathrm{M} \mathrm{KPF}_{6}-\mathrm{MeCN}$ solution. 


\section{Representative Reported Organic and Organometallic Catholytes}

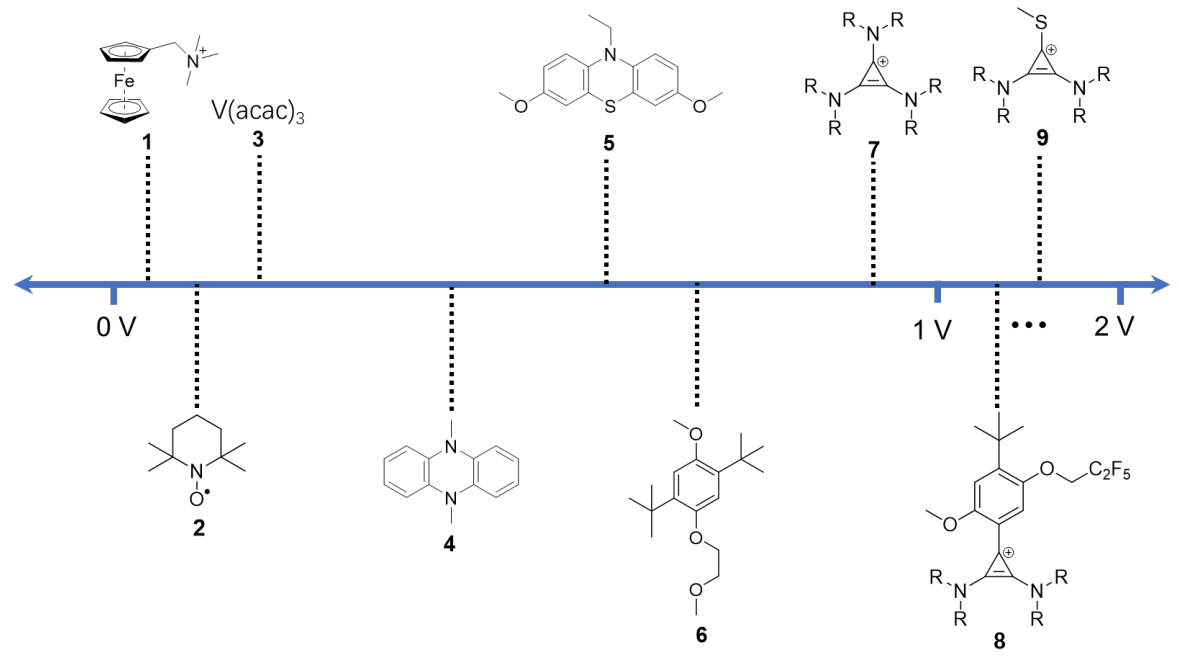

Table S4. Representative Reported Organic and Organometallic Catholytes

\begin{tabular}{|c|c|c|c|}
\hline Compound & Redox Potential & Cyclability & Solubility \\
\hline $\mathbf{1}^{12}$ & $0.27 \mathrm{~V}$ vs $. \mathrm{Fc} / \mathrm{Fc}^{+}$ & $\begin{array}{l}91.8 \% \text { capacity at } \\
100 \text { cycles }\end{array}$ & $\begin{array}{l}\text { neutral: } 0.98 \mathrm{M} \text { in pure } \\
\mathrm{MeCN}\end{array}$ \\
\hline $2^{13}$ & $0.3 \mathrm{~V}$ vs $\mathrm{Ag} / \mathrm{Ag}^{+}$ & $\begin{array}{l}82 \% \text { capacity at } 100 \\
\text { cycles }\end{array}$ & 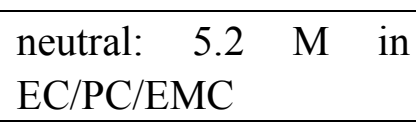 \\
\hline $3^{14,15}$ & $0.45 \mathrm{~V}$ vs $\mathrm{Ag} / \mathrm{Ag}^{+}$ & $\begin{array}{l}<20 \% \text { capacity at } 10 \\
\text { cycles }\end{array}$ & $\begin{array}{l}\text { Neutral: } 0.58 \quad M \quad \text { in } \\
\text { MeCN }\end{array}$ \\
\hline $4^{16}$ & $\begin{array}{c}1^{\text {st. }}-0.15 \mathrm{~V} \\
2^{\text {nd }}: 0.6 \mathrm{~V} \text { vs Ag/ } / \mathrm{Ag}^{+}\end{array}$ & $\begin{array}{l}90 \% \text { capacity at } 80 \\
\text { cycles }\end{array}$ & $\begin{array}{l}\text { neutral: } 60 \mathrm{mM} \text { in pure } \\
\mathrm{MeCN}\end{array}$ \\
\hline $5^{17}$ & $\begin{array}{c}1^{\text {st: }} 0.068 \mathrm{~V} \\
2^{\text {nd }}: 0.63 \mathrm{~V} \text { vs } \mathrm{Fc} / \mathrm{Fc}^{+}\end{array}$ & $\begin{array}{l}93 \% \text { capacity at } 50 \\
\text { cycles }\end{array}$ & $\begin{array}{l}\text { neutral: } 0.05 \mathrm{M} \text {; cation: } \\
0.15 \mathrm{M} \text {; dication: } 0.1 \mathrm{M} \\
\text { in } 1 \mathrm{M} \text { LiTFSI in PC }\end{array}$ \\
\hline $6^{18}$ & $0.69 \mathrm{~V}$ vs $\mathrm{Ag} / \mathrm{Ag}^{+}$ & $\begin{array}{l}75 \% \text { capacity at } 30 \\
\text { cycles }\end{array}$ & Oil \\
\hline $7^{9}$ & $0.82 \mathrm{~V}$ vs $\mathrm{Fc} / \mathrm{Fc}^{+}$ & $\begin{array}{l}>97 \% \text { capacity at } 200 \\
\text { cycles }\end{array}$ & $\begin{array}{l}\text { cation: } 1.5 \mathrm{M} \text {, dication: } \\
0.081 \mathrm{M} \text { in pure } \mathrm{MeCN}\end{array}$ \\
\hline 8 (this work) & $1.19 \mathrm{~V}$ vs $\mathrm{Fc} / \mathrm{Fc}^{+}$ & $\begin{array}{l}>90 \% \text { capacity at } 300 \\
\text { cycles }\end{array}$ & $\begin{array}{l}\text { cation: } 1.0 \mathrm{M} \text { in pure } \\
\mathrm{MeCN}\end{array}$ \\
\hline $\mathbf{9}^{19}$ & $1.33 \mathrm{~V}$ vs $\mathrm{Fc} / \mathrm{Fc}^{+}$ & $\begin{array}{l}90 \% \text { capacity at } 156 \\
\text { cycles }\end{array}$ & $\begin{array}{l}\text { cation: } 0.58 \mathrm{M} \text { in pure } \\
\mathrm{MeCN} \text {, dication: }>0.2 \\
\mathrm{M} \text { in } 0.5 \mathrm{M} \mathrm{NBu}_{4} \mathrm{PF}_{6}\end{array}$ \\
\hline
\end{tabular}




\section{Cost Analysis of the Synthesis of $\left[3^{\mathrm{g}+}\right]\left[\mathrm{PF}_{6}\right]$}

All Prices from Alibaba.com and transferred to $\$ / \mathrm{mol}$
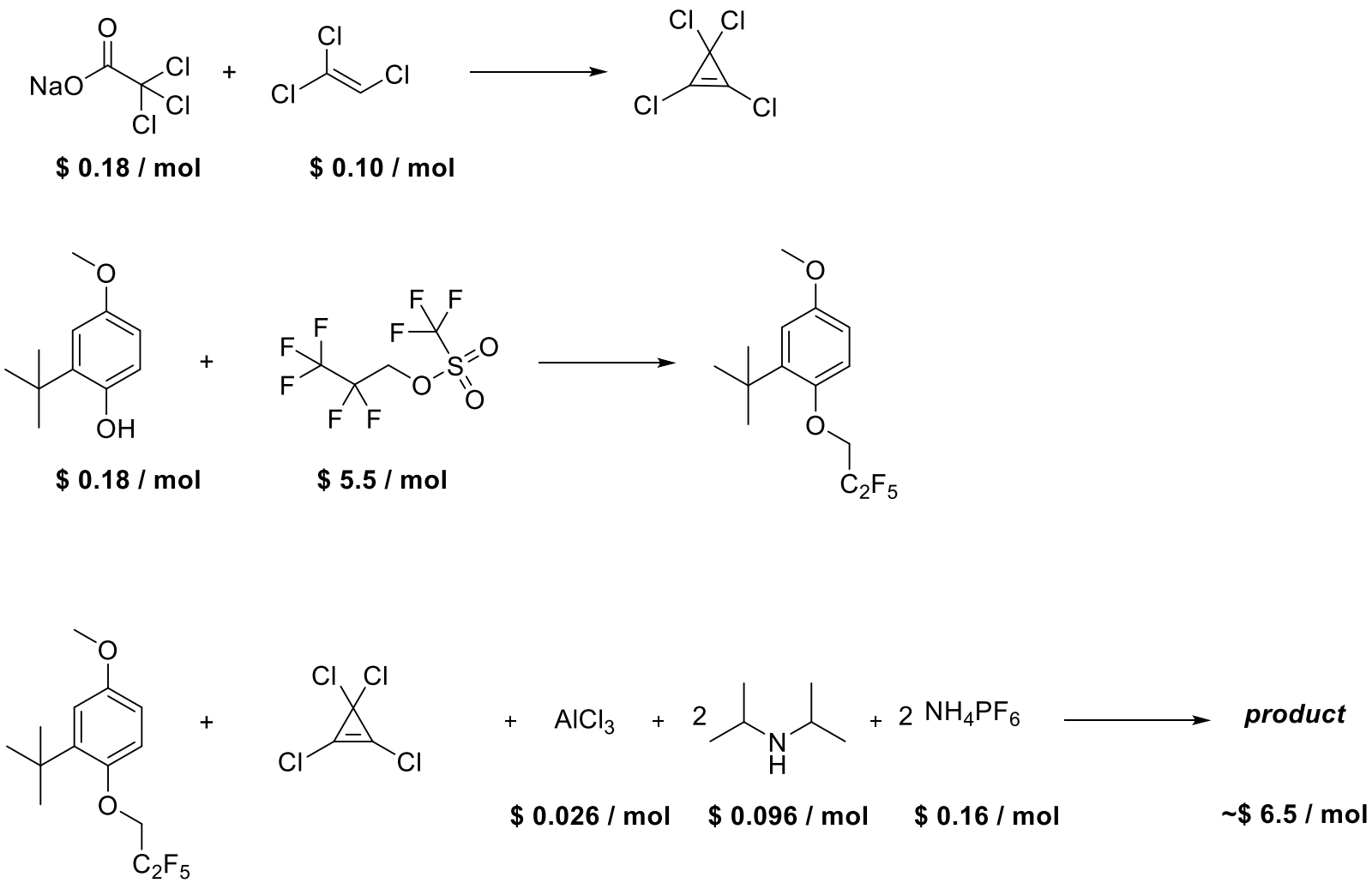

Figure S17. Cost analysis for the synthesis of $\left[\mathbf{3 g}^{+}\right]\left[\mathrm{PF}_{6}\right]$. 


\section{References}

(1) Weng, W.; Tao, Y.; Zhang, Z.; Redfern, P. C.; Curtiss, L. A.; Amine, K. Asymmetric Form of Redox Shuttle Based on 1,4-Di-Tert-Butyl-2,5-Dimethoxybenzene. J. Electrochem. Soc. 2013, 160 (10), A1711-A1715. https://doi.org/10.1149/2.044310jes.

(2) Silcox, B.; Zhang, J.; Shkrob, I. A.; Thompson, L.; Zhang, L. On Transferability of Performance Metrics for Redox-Active Molecules. J. Phys. Chem. C 2019, 123 (27), 16516-16524. https://doi.org/10.1021/acs.jpcc.9b02230.

(3) Moon, K.; Kaifer, A. E. Modes of Binding Interaction between Viologen Guests and the Cucurbit[7]Uril Host. Org. Lett. 2004, 6 (2), 185-188. https://doi.org/10.1021/o1035967x.

(4) Robinson, S. G.; Yan, Y.; Hendriks, K. H.; Sanford, M. S.; Sigman, M. S. Developing a Predictive Solubility Model for Monomeric and Oligomeric Cyclopropenium-Based Flow Battery Catholytes. J. Am. Chem. Soc. 2019, 141 (26), 10171-10176. https://doi.org/10.1021/jacs.9b04270.

(5) Rosenau, C. P.; Jelier, B. J.; Gossert, A. D.; Togni, A. Exposing the Origins of Irreproducibility in Fluorine NMR Spectroscopy. Angewandte Chemie International Edition 2018, 57 (30), 9528-9533. https://doi.org/10.1002/anie.201802620.

(6) Chickos, J. S.; Patton, E.; West, R. Aryltrichlorocyclopropenes and Arylhydroxycyclopropenones. J. Org. Chem. 1974, 39 (12), 1647-1650. https://doi.org/10.1021/jo00925a009.

(7) Wu, M. T.; Taub, D.; Patchett, A. A. Preparation and Hydrolysis of Phenylbisdialkylaminocyclopropenium Cations. Tetrahedron Letters 1976, 17 (28), 2405 2408. https://doi.org/10.1016/0040-4039(76)90004-6.

(8) Milshtein, J. D.; Kaur, A. P.; Casselman, M. D.; Kowalski, J. A.; Modekrutti, S.; Zhang, P. L.; Harsha Attanayake, N.; Elliott, C. F.; Parkin, S. R.; Risko, C.; Brushett, F. R.; Odom, S. A. High Current Density, Long Duration Cycling of Soluble Organic Active Species for Non-Aqueous Redox Flow Batteries. Energy Environ. Sci. 2016, 9 (11), 3531-3543. https://doi.org/10.1039/C6EE02027E.

(9) Sevov, C. S.; Samaroo, S. K.; Sanford, M. S. Cyclopropenium Salts as Cyclable, HighPotential Catholytes in Nonaqueous Media. Advanced Energy Materials 2017, 7 (5), 1602027. https://doi.org/10.1002/aenm.201602027.

(10) Elgrishi, N.; Rountree, K. J.; McCarthy, B. D.; Rountree, E. S.; Eisenhart, T. T.; Dempsey, J. L. A Practical Beginner's Guide to Cyclic Voltammetry. J. Chem. Educ. 2018, 95 (2), 197-206. https://doi.org/10.1021/acs.jchemed.7b00361.

(11) Nicholson, R. S. Theory and Application of Cyclic Voltammetry for Measurement of Electrode Reaction Kinetics. Anal. Chem. 1965, 37 (11), 1351-1355. https://doi.org/10.1021/ac60230a016.

(12) Hu, B.; Liu, T. L. Two Electron Utilization of Methyl Viologen Anolyte in Nonaqueous Organic Redox Flow Battery. Journal of Energy Chemistry 2018, 27 (5), 1326-1332. https://doi.org/10.1016/j.jechem.2018.02.014. 
(13) Wei, X.; Xu, W.; Vijayakumar, M.; Cosimbescu, L.; Liu, T.; Sprenkle, V.; Wang, W. TEMPO-Based Catholyte for High-Energy Density Nonaqueous Redox Flow Batteries. Advanced Materials 2014, 26 (45), 7649-7653. https://doi.org/10.1002/adma.201403746.

(14) Shinkle, A. A.; Sleightholme, A. E. S.; Griffith, L. D.; Thompson, L. T.; Monroe, C. W. Degradation Mechanisms in the Non-Aqueous Vanadium Acetylacetonate Redox Flow Battery. Journal of Power Sources 2012, 206, 490-496.

https://doi.org/10.1016/j.jpowsour.2010.12.096.

(15) Escalante-García, I. L.; Wainright, J. S.; Thompson, L. T.; Savinell, R. F. Performance of a Non-Aqueous Vanadium Acetylacetonate Prototype Redox Flow Battery: Examination of Separators and Capacity Decay. J. Electrochem. Soc. 2015, 162 (3), A363-A372. https://doi.org/10.1149/2.0471503jes.

(16) Kwon, G.; Lee, S.; Hwang, J.; Shim, H.-S.; Lee, B.; Lee, M. H.; Ko, Y.; Jung, S.-K.; $\mathrm{Ku}, \mathrm{K}$.; Hong, J.; Kang, K. Multi-Redox Molecule for High-Energy Redox Flow Batteries. Joule 2018, 2 (9), 1771-1782. https://doi.org/10.1016/j.joule.2018.05.014.

(17) A. Kowalski, J.; D. Casselman, M.; Preet Kaur, A.; D. Milshtein, J.; F. Elliott, C.; Modekrutti, S.; Harsha Attanayake, N.; Zhang, N.; R. Parkin, S.; Risko, C.; R. Brushett, F.; A. Odom, S. A Stable Two-Electron-Donating Phenothiazine for Application in Nonaqueous Redox Flow Batteries. Journal of Materials Chemistry A 2017, 5 (46), 2437124379. https://doi.org/10.1039/C7TA05883G.

(18) Huang, J.; Cheng, L.; Assary, R. S.; Wang, P.; Xue, Z.; Burrell, A. K.; Curtiss, L. A.; Zhang, L. Liquid Catholyte Molecules for Nonaqueous Redox Flow Batteries. Advanced Energy Materials 2015, 5 (6), 1401782. https://doi.org/10.1002/aenm.201401782.

(19) Yan, Y.; Robinson, S. G.; Sigman, M. S.; Sanford, M. S. Mechanism-Based Design of a High-Potential Catholyte Enables a 3.2 V All-Organic Nonaqueous Redox Flow Battery. J. Am. Chem. Soc. 2019, 141 (38), 15301-15306. https://doi.org/10.1021/jacs.9b07345. 